IZA DP No. 8895

The Effect of Public Pension Wealth on

Saving and Expenditure

Marta Lachowska

Michat Myck

February 2015

Forschungsinstitut

zur Zukunft der Arbeit

Institute for the Study

of Labor 


\title{
The Effect of Public Pension Wealth on Saving and Expenditure
}

\author{
Marta Lachowska \\ W.E. Upjohn Institute \\ and Stockholm University \\ Michał Myck \\ Centre for Economic Analysis (CenEA), \\ DIW Berlin and IZA \\ Discussion Paper No. 8895 \\ February 2015
}

\author{
IZA \\ P.O. Box 7240 \\ 53072 Bonn \\ Germany \\ Phone: +49-228-3894-0 \\ Fax: +49-228-3894-180 \\ E-mail: iza@iza.org
}

\begin{abstract}
Any opinions expressed here are those of the author(s) and not those of IZA. Research published in this series may include views on policy, but the institute itself takes no institutional policy positions. The IZA research network is committed to the IZA Guiding Principles of Research Integrity.

The Institute for the Study of Labor (IZA) in Bonn is a local and virtual international research center and a place of communication between science, politics and business. IZA is an independent nonprofit organization supported by Deutsche Post Foundation. The center is associated with the University of Bonn and offers a stimulating research environment through its international network, workshops and conferences, data service, project support, research visits and doctoral program. IZA engages in (i) original and internationally competitive research in all fields of labor economics, (ii) development of policy concepts, and (iii) dissemination of research results and concepts to the interested public.
\end{abstract}

IZA Discussion Papers often represent preliminary work and are circulated to encourage discussion. Citation of such a paper should account for its provisional character. A revised version may be available directly from the author. 
IZA Discussion Paper No. 8895

February 2015

\section{ABSTRACT \\ The Effect of Public Pension Wealth on Saving and Expenditure*}

In order to study whether public pension systems displace private saving, we use the quasiexperimental variation in pension wealth created by Poland's 1999 pension reform. Using the 1997-2003 Polish Household Budget Surveys, we begin by estimating "difference-indifferences" regressions, where we compare household saving and expenditure across time and between cohorts affected and unaffected by the reform. Next, we estimate the extent of crowd-out by using two-stage least squares. We identify the effect of pension wealth on private saving by using the cohort-by-time variation in pension wealth that is explained by the reform. We find that one additional Polish zloty, or PLN, of pension wealth crowds out about 0.24 PLN in household saving. We also find heterogeneity in responses. For the middle-aged cohorts, we find a large public pension crowd-out of private saving (about 0.54 PLN of private saving for each 1 PLN of public pension wealth), while the crowd-out for younger cohorts equals about 0.30 PLN of private saving per 1 PLN. Finally, we find a close-to-complete crowd-out among highly-educated households.

JEL Classification: E21, H55, I38, P35

Keywords: pension reforms, crowd-out effect, retirement saving, difference-in-differences, natural experiment

Corresponding author:

Michał Myck

Centre for Economic Analysis (CenEA)

ul. Królowej Korony Polskiej 25

70-486 Szczecin

Poland

E-mail: mmyck@cenea.org.pl

\footnotetext{
* We thank Orazio Attanasio, Richard Blundell, Manuel Flores, Krzysztof Karbownik, Wojciech Kopczuk, Joanna Lahey, Jeff Larrimore, Susann Rohwedder, Mel Stephens, Federica Teppa, TzuTing Yang, Guglielmo Weber, and the audiences at the W.E. Upjohn Institute, University of Michigan, Midwest Economic Association meetings, Institute for Fiscal Studies, Netspar International Pension workshop, WIEM conference, the International Institute for Public Finance, the "Optimizing over the Life Cycle" workshop, APPAM, and the National Tax Association for their comments and suggestions. We gratefully acknowledge the financial support from the Polish National Science Centre (NCN) through grant number 2012/05/B/HS4/01417. Data from the Polish Household Budget Surveys used in this paper have been made available by the Polish Central Statistical Office, which takes no responsibility for any results and interpretation. We are grateful to Agnieszka Chłoń-Domińczak for helping us understand the details of the pension reform. We thank Ewa Laskowska for helping us with the news searches of the archives of Gazeta Wyborcza, Michał Kundera for assistance with the data, and Ben Jones for careful proofreading of the paper. All errors are our own.
} 


\section{Introduction}

In 1999, a drastic reform of the public pension system was launched in Poland. Prior to the reform, Poland offered relatively generous pension benefits and early retirement options. Deemed to be unsustainable, the pension system was reformed in 1999. One of the more salient consequences of this reform was the greatly reduced generosity of pension benefits for those 50 years old or younger at the time of the reform.

This paper exploits this reduction in the generosity of public pensions induced by the 1999 reform to examine whether public pension systems have a displacing effect on private saving. Our aim is to estimate public pension crowd-out-i.e., to determine by how much a unit increase in public pension wealth depresses private saving. The extent of public pension crowd-out is a key issue in the design of every pension system and thus in any debate on reforming public pensions. With public pension systems in many countries facing significant financial pressures because of higher life expectancy and low fertility, reforming pensions is one of the top policy challenges. Understanding the relationship between pension wealth and private saving should inform the debate about the behavioral response to changes to Social Security and other public pensions. Specifically, it should help us understand how much households would save on their own for retirement in the situation of lower generosity of a mandated pension system.

To estimate the crowd-out, we use the fact that the 1999 pension reform had a differential impact on individuals depending on their year of birth. Individuals who were older than 50 years at the time of the reform were allowed to stay in the pre-reform system with high benefit-to-salary replacement rates and were not directly affected by the reform. Individuals who were 50 years old or younger at the time of the reform were to receive pension benefits computed according to a much less generous post-reform pension formula. The reform 
created a large variation across cohorts in expected pension wealth, thus creating a setting similar to that of a natural experiment.

We begin by estimating a set of difference-in-differences regressions where we calculate the change in household saving and expenditure before and after the reform for the cohorts affected and unaffected by the reform. This procedure allows us to control for unobserved time-invariant differences between various cohorts and for secular time trends in the outcome variables. In order to estimate the public pension crowd-out, we complement the simple difference-in-differences estimation with a more structural approach. For each household, we model the expected pension wealth under the pre-reform and post-reform legislation and relate this variable to household saving. Because pension wealth is likely to be endogenous with respect to saving, we use the instrumental variables technique. Specifically, to identify the degree of crowd-out, we use variation across cohorts and time created by the reform to construct year-of-birth cohort-by-time dummies and use them as instrumental variables for pension wealth. By doing so, we can separate the variation in pension wealth that is due to unobserved heterogeneity, such as differences in taste for saving, and identify public pension crowd-out by using the variation in pension wealth created by the reform.

The quasi-experimental variation is valuable because there is theoretical ambiguity as to whether public pension systems crowd out private saving. On the one hand, if public pension wealth is a perfect substitute for private wealth, then the canonical life-cycle model predicts there to be a one-for-one relationship between a marginal increase in pension wealth and a decrease in private saving. On the other hand, Feldstein (1974) suggests that if the pension system makes people retire earlier, thus extending the period when individuals consume out of accumulated assets, this might increase saving. If so, then a marginal increase in public pension wealth will crowd in saving. Furthermore, public pension wealth is usually an illiquid asset, which may complicate any sharp theoretical predictions about the relationship between 
private saving and mandatory public pension saving. The degree of public pension crowd-out could also be context-specific: for example, at the time of the reform, Poland had relatively undeveloped capital markets, and so the savings of Polish households may react differently from the savings of households in a more developed economy. Also, the saving decisions of some individuals may be unaffected by changes in pension wealth because they are not interested in how the pension system works or are very present-biased in their discounting of the future. ${ }^{1}$ Finally, as pointed out by Gale (1997), individuals may save for other reasons than retirement and may view their voluntary saving as a different form of saving from that mandated by the pension system.

In addition to theoretical uncertainty, the empirical literature on public pension crowd-out has been inconclusive. Feldstein (1974) finds that household savings and U.S. Social Security wealth are close substitutes and concludes that Social Security depresses personal saving by up to 50 percent, hence reducing the stock of capital and national income. Among other studies that have found large crowd-out effects are Feldstein and Pellechio (1979), Bernheim (1987), and Alessie, Kapteyn, and Klijn (1997). Other research has found modest crowd-out effects (King and Dicks-Mireaux 1982; Hubbard 1986), while Hurd, Michaud, and Rohwedder (2012) find relatively low crowd-outs, ranging from 0.20 to 0.33 . Furthermore, Pozo and Woodbury (1986) find support for a Social Security crowd-in and also find that Social Security wealth induces people to retire early. ${ }^{2,3}$

The dispute over the magnitude and direction of crowd-out are in part due to different empirical strategies. A key difficulty in estimating the relationship between pension wealth and household saving lies in how to account for unobserved traits that influence saving

\footnotetext{
${ }^{1}$ Bottazzi, Jappelli, and Padula (2006) use data on how well informed individuals are about pensions and find the largest crowd-out effects among the well-informed groups.

${ }^{2}$ Katona (1965) also finds evidence of private pension crowd-in.

${ }^{3}$ In addition to the dispute over the displacing effects of public pensions, there exists a closely related literature concerned with the displacing effects of private pensions (e.g., Cagan [1965], Katona [1965], Munnell [1976], Engelhardt and Kumar [2011], and Yang [2014]) and tax-deferred pension accounts (e.g., Venti and Wise [1990], Gale and Scholz [1994], and Chetty et al. [2014]). Bernheim (2002) and Gale (2005) provide literature reviews.
} 
decisions as well as the determinants of pension wealth (see Gale [1998] for a discussion of other biases in the estimates of crowd-out). More recently, the literature on crowd-out effects has searched for exogenous shifts in pension wealth as a source of identification. Attanasio and Rohwedder (2003), Attanasio and Brugiavini (2003), Bottazzi, Jappelli, and Padula (2006), Aguila (2011), Feng, He, and Sato (2011), and Banerjee (2011) use differential impacts across groups and time created by pension reforms as a source of variation in pension wealth and apply variants of the difference-in-differences approach to estimate the crowd-out effect. Whereas Attanasio and Rohwedder (2003), Attanasio and Brugiavini (2003), Bottazzi, Jappelli, and Padula (2006), and Aguila (2011) find crowd-out effects ranging between 0.50 and 0.75, Feng, He, and Sato (2011) report modest crowd-out, ranging between 0.10 and $0.16 .{ }^{4}$ In sum, the literature relying on quasi-experimental variation, too, remains in dispute about the magnitude of public pension crowd-out.

In our main results, where following the literature, we assume that the subjective discount factor equals 0.98 percent, we find that one additional Polish zloty (PLN) of pension wealth crowds out about 0.24 PLN in household saving and crowds in about 0.21 PLN in household consumption. We also find heterogeneity in responses. The crowd-out of saving for the older and middle-aged cohort is large or close to complete. Our findings also show that for highly educated households, public pension wealth and private saving are close substitutes.

We also present several sensitivity checks, where we vary our assumptions regarding the households' subjective annual discount factor, projections of future earnings and pension wealth, and sample specifications. We show that the main results are robust to alternative sample cuts and assumptions regarding computation of pension wealth. We also show that the degree of public pension crowd-out is inversely related to how heavily households discount the future. If the annual discount factor equals 0.90 , then crowd-out is almost zero, and the

\footnotetext{
${ }^{4}$ Feng, He, and Sato (2011) study the effects of expanding a pension system, whereas most other papers study the response of household saving to reductions in pension benefit generosity.
} 
two-stage least squares (2SLS) estimates are similar to ordinary least squares (OLS) estimates. On the other hand, if we set the annual discount factor at 0.999, the overall crowdout is estimated to be approximately 0.40 .

The rest of the paper is organized as follows. Section 2 provides background information about Poland's public pension system in the years before and after the reform. Section 3 describes the data and variables from the Polish Household Budget Surveys and the empirical strategy used to analyze the data. Section 4 describes the results, and Section 5 discusses the findings. The final section draws conclusions. In order to keep the discussion as focused as possible on the main subject of the paper, we relegate the detailed description of variable definitions and the construction of the sample used for analysis to Appendix A.

\section{A brief overview of Poland's 1999 pension reform ${ }^{5}$}

In the early 1990s Poland had, in relative terms, a generous public pension system financed on a pay-as-you-go basis. However, the combination of ample use of early retirement options, increases in life expectancy, and low fertility raised questions about the system's fiscal sustainability. In order to help finance the pension system, the contribution rate was successively raised after the early 1990s. Soon it became apparent, though, that these changes provided only temporary solutions and that Poland needed a radical reform of its public pension system. The initial steps toward a major reform of the system were formulated by the left-wing coalition in 1994, and in the following years negotiations were held regarding the choice of funding and transition rules.

The plan to reform the pension system moved forward after the electoral victory of the center-right-wing coalition in the fall of 1997. Although it was anticipated that a pension reform would take place in some form, the details of who would be affected and to what

\footnotetext{
${ }^{5}$ This section is based on Chłoń-Domińczak (2002), who provides a detailed description of Poland's pension system and the events leading up to the reform.
} 
extent were still a matter of debate in 1998. The vote was passed in October 1998, and the new pension system was launched on January 1, 1999. ${ }^{6}$ As Chłoń-Domińczak (2002) points out, one of the factors driving the haste in reforming the pension system was a strong public backing of pension reform, which perceived the old pension system as a carry-over from communist days.

Arguably, the most salient components of the reform were the following:

- To relate the generosity of the pension benefit formula to lifetime earnings profiles, thus providing a clearer incentive to postpone retirement. Projections that assumed no change in the timing of retirement forecast alarming drops in the replacement rates (defined as the ratio of first pension benefit to last salary), from about 65-76 percent to about 40-60 percent for men. For women, this drop would be as high as from 70 percent in the pre-reform system to a 30-50 percent post-reform replacement rate. This dramatic reduction for women stems from the fact that the post-reform pension formula rewards longer careers, whereas women tend to have a more spotty labor force participation.

- To "nudge" the public to take an interest in their pensions by altering the formula for the pay-as-you-go part to resemble the structure of a funded defined contribution pension—a so-called notionally defined contribution (NDC) pension. ${ }^{7}$ NDC pensions are accounts of pension rights, based on an individual's entire earnings profile, with a specified rate of return usually based on the economy-wide wage growth. The NDC pension is funded by current contributions, but the formula is set up to mimic a fully funded plan (hence the term "notional”). The reform also introduced a fully funded defined contribution pension plan, membership in which was obligatory for the

\footnotetext{
${ }^{6}$ See Hausner (2002) and Chłoń-Domińczak (2002) for a description of the political negotiations preceding the reform.

${ }^{7}$ Such plans are also called nonfinancial defined contribution plans. A similar system has also been adopted in Sweden; see Holzmann, Palmer, and Robalino (2012).
} 
youngest cohorts. Contributions to these funds initially constituted 7.3 percent of total retirement contributions among those who joined the funds.

- To make the system more actuarially fair-i.e., structuring the benefit formula so that in expectation the present value of contributions to the system would equal the present value of future benefits.

- To increase the effective retirement age toward the statutory retirement age. Statutory retirement age was not affected by the reform and stayed at 60 years for women and 65 years for men. Because of a variety of early retirement options, the effective retirement age before the reform was 59 years for men and 55 years for women. ${ }^{8}$

- Limiting the scope of early retirement privileges for various occupations, broadly defined as "demanding." For example, miners could retire after contributing to the system for 25 years, regardless of age (Perraudin and Pujol 1994).

In Table 1, we highlight more of the differences between the pre-reform and reformed pension systems. Generally, pension reforms tend to be implemented gradually to allow individuals to adjust to their implications. For the 1999 reform, it will take until the 2030s before the cohorts fully covered by the reformed system will transition to retirement. However, since life-cycle theory suggests that households are forward-looking and form their saving decisions by taking into consideration expectations of their lifetime income, a large change in future pension benefits may induce households to alter their saving behavior even if retirement is years away. Therefore, in the second column of Table 1, we describe the features of the post-reform system once it reaches a "steady state."

[Table 1 here]

\footnotetext{
${ }^{8}$ Reaching an agreement regarding the early retirement privileges proved to be one of the major obstacles of the pension reform. The negotiations illustrated that retaining the option to retire early is a "focal point" of the pension debate in Poland. In the end, a compromise was reached where the transition cohorts working in certain occupations could still retire early, and also women retained the possibility to retire early; see Table 2 for details. We discuss the existing evidence of labor supply effects of the 1999 pension reform in subsection 3.5.
} 


\subsection{The impact of the reform across cohorts}

The gradual implementation of the reform created a variation in how it affected individuals depending on their year of birth; see Table 2. This lends itself to studying the impact of the reform on four different cohorts: one cohort unaffected directly by the reform and three cohorts affected by the reform with varying intensity.

- First, all those born before 1949 (i.e., those who were older than 50 years at the time of the reform) remained in the pre-reform system. We refer to this cohort as the comparison cohort.

- Second, the first five year-of-birth cohorts of women, those born from 1949 to 1953, would receive a mix of pre-reform benefits and post-reform benefits; see Table 2 . This exception was motivated by the fact that the new pension formula punishes short careers, and many women of this generation had relatively short careers. This group retained some early retirement options. We refer to this first "treated" cohort born between 1949 and 1953 as the older cohort.

- Third, those born after January 1, 1949, but before January 1, 1969 (i.e., those between 30 and 50 years of age at the time of the reform), also retained early retirement privileges, but had their pension formula calculated according to the postreform formula. Hence, even if these individuals choose to exercise the option to retire early, their pension benefit will be calculated according to the post-reform formula. Since the post-reform formula rewards longer careers, one might suspect that the saving rate of these groups would increase in order to finance their longer retirement period. We refer to this second "treated" cohort, born between 1954 and 1968, as the middle-aged cohort.

- Fourth, those born after 1969 (i.e., those younger than 30 at the time of the reform) are fully in the post-reform pension system, with no early retirement privileges and no 
exemptions to the post-reform pension formula. We refer to this last "treated" cohort as the younger cohort.

[Table 2 here]

\subsection{Was the public aware of the pension reform?}

Existing literature on financial literacy (e.g., Gustman and Steinmeier [2005], Lusardi and Mitchell [2014]) has shown that people may not fully understand how the pension system works. In order to expect a pension reform to have an effect on saving, the public should at least know about the main provisions of the reform.

To put the 1999 pension reform in perspective, it is worthwhile to point out that it was one of four major reforms implemented at the same time. The other changes included a reform of the education system, a new local government and administration structure, and a reform of the health care system. Chłon-Domińczak (2002) points out that one of the factors motivating the pension reform was a strong public support for the change.

To develop a sense of how "Main Street” might have perceived the pension reform, we searched the archives of Poland's major national daily newspaper, Gazeta Wyborcza, for the terms “pension reform," “pension system," “reform of pension system,” and “pension” for the years 1997-1999. Based on this collection of articles, one could note that one salient feature of the coverage was the emphasis on the cohort-specific nature of the reform. The media coverage included "information boxes" that showed practical examples of what the pension formula would be for certain types of workers in the pre-reform and post-reform systems. This coverage reflects a general interest in the consequences of the reform and suggests that the public should at least have been aware of the main features of the implemented changes, and in particular of the fact that the pension reform would have a differential impact depending on one's year of birth. It is of course natural that the awareness of the reform 
would differ across different groups of the society, but it is clear that there was substantial coverage of the reform in the media.

Reporting about the pension reform continued in 1999, suggesting that there was continued demand for information about the pension reform. Since information may diffuse slowly, it is reasonable to assume that some people might not have immediately understood the incentives of the post-reform pension system. As we describe below, for that reason we follow cohorts over a five-year period after the implementation of the reform.

\section{Data and Methods}

\subsection{Data}

Our data come from the Polish Household Budget Surveys (Badanie Budżetów Gospodarstw Domowych, or BBGD), collected by the Polish Central Statistical Office; see Barlik and Siwiak (2011). The BBGD is a monthly survey of household incomes and expenditures that also collects demographic data. Each month about 3,100 households are interviewed, which adds up to about 37,500 households annually (about 0.3 percent of Poland's population). The BBGD collects information on monthly household expenditure, income from different sources including labor income and social security benefits, key household durables and equipment, and detailed demographic information.

We use data for the years 1997-2003; this allows us to observe four years after the reform year of 1999. We include these years to allow for any lag during which households adjust their behavior after reform. We use two years before the reform, 1997 and 1998, to test for anticipation effects and group by time trends. If there are pre-reform differences in outcomes between groups affected by the reform and groups unaffected by the reform, then we must question whether the responses we observe after the reform are really due to the reform. 
Although part of the BBGD sample includes a rolling panel element, the design of the panel roll-out changed over the years and the panel part is too small for the purpose of our study, and so we use the BBGD as pooled cross-sectional data. Hence, our regression sample consists of households whose head was born between 1937 and 1980, and for each year we restrict the sample to include 18- to 65-year-old heads of household. Appendix A details additional sample restrictions.

Following the literature, we construct household saving as the residual between household available income and total household expenditure. The saving rate is defined as household saving divided by household available income.

In order to relate saving to pension wealth, we need to construct the pension wealth based on the demographic and income information in the BBGD and institutional regulations. We define household expected pension wealth as the present value of the sum of future pension benefits of both spouses, adjusted by survival probabilities obtained from the Polish life tables (see Brugiavini, Maser, and Sundén [2005] for a discussion of approaches in estimating pension wealth).

In order to compute pension wealth, first we need to forecast lifetime earnings profiles for both spouses. We estimate labor income profiles for heads of households and spouses separately. To forecast pension wealth, one needs detailed knowledge of the pension legislation before and after the reform. For the computation of pension wealth, we need to make assumptions about labor supply decisions that are plausibly "typical.” Appendix A details the assumptions we make at this stage of the analysis. The model could be made more realistic, but the objective of our paper is not to model pension wealth level as an end in itself, but rather as the relationship between pension wealth and private saving at the margin. Later in the paper, we check the sensitivity of our assumptions by conducting several robustness checks regarding the computation of pension wealth. 
In order to account for cross-sectional differences in planning horizons of the households and different points in individual life cycles of when the reform occurred, we correct the expected pension wealth by a discrete-time version of “Gale’s Q” (Gale 1998) adjustment factor as derived in Attanasio and Brugiavini (2003) and Attanasio and Rohwedder (2003). Following this literature (Attanasio and Brugiavini 2003; Attanasio and Rohwedder 2003; Bottazzi, Jappelli, and Padula 2006), we assume that the subjective discount rate equals 2 percent and that the coefficient of relative risk aversion equals 1 . We discuss this factor in Appendix B and conduct sensitivity checks of these assumptions later in the paper.

\subsection{Descriptive Statistics}

Table 3 presents the descriptive statistics for the estimation sample. For income, expenditure, pension wealth, and saving variables, we report the sample mean, standard deviation, and median. For the other variables, we report means and standard deviation (although not for proportions).

[Table 3 here]

The average saving rate in the BBGD is relatively low, about 2 percent, which is due to a large number of negative values, but the median is about 9 percent. $^{9}$ On average, 64 percent of the analysis sample saves a positive amount. Turning to the computed pension benefit, we see that, on average, the ratio of household gross pension benefits to current gross household labor income is about 0.50 .

A lower pension benefit implies a lower pension wealth, but it is relatively difficult to interpret changes in pension wealth. Hence, in Figure 1 we compute the median pension benefit replacement rate under the pre- and post-reform legislation for the cohort unaffected by the reform and the three affected cohorts. We calculate the replacement rate using data in

\footnotetext{
${ }^{9}$ The household net saving rate in Poland between 1997 and 2003 was about 10.5 percent (OECD 2010).
} 
the BBGD and define it as the ratio of the first pension benefit of the head of household to his or her last pre-retirement salary.

[Figure 1 here]

Figure 1 shows the drop in replacement rates that is driving the variation in pension wealth. Prior to the reform, all of the cohorts considered in our analysis could expect a median replacement rate of about $60-64$ percent. ${ }^{10}$ After the reform, the median replacement rate for the comparison cohort (born between 1937 and 1948 and unaffected directly by the reform) remained at about 60 percent. After the reform, the median replacement rate falls for the older, the middle-aged, and the younger cohort by about 20 percentage points. ${ }^{11}$

Although the percentage-point decrease is similar across the affected cohorts, we expect cohorts late in their life cycle to react more strongly than the younger cohort. This difference in treatment intensity allows us to study whether changes in saving behavior differ in the direction predicted by the life-cycle model.

\subsection{Consequences of the reform: identifying effects using difference-in-}

\section{differences}

In order to investigate whether the 1999 reform did have an impact on saving behavior, we begin by comparing the mean outcomes for the cohorts affected by the reform and the mean outcomes of cohorts unaffected by the reform (those born before 1949), before and after the reform. To do so, we estimate a set of multiyear difference-in-differences regressions, such as the following:

$$
y_{i t}=\alpha_{t}+\alpha_{g}+\alpha_{t g}+x_{i t} \beta+\varepsilon_{i t}
$$

where $y_{i t}$ is an outcome, $\alpha_{t}$ stands for time effects (year 1998 is the omitted category), $\alpha_{g}$ denotes the cohort fixed effects (the unaffected cohort born 1937-1948 is the omitted

\footnotetext{
${ }^{10}$ Productivity is higher for younger cohorts, which accounts for the secular increase in the replacement rates.

${ }^{11}$ Since two-thirds of the heads of household are men, the "milder" treatment that women in the older cohort experienced is not reflected in the bar chart.
} 
category), and $\alpha_{\mathrm{tg}}$ is the interaction between time dummies and cohort dummies. Since the BBGD contains too few observations per each year of birth to conduct an age-based regression-discontinuity design study, instead we compare the outcomes of the older cohort (those born from 1949 to 1953), the middle-aged cohort (those born from 1954 to 1968), and the younger cohort (those born after 1969) separately to the outcomes of the comparison cohort. $^{12}$

We focus on the estimated effects on the interaction terms between the time dummies and cohort dummies, $\alpha_{t g}$. These interacted terms are relative to the cohort born between the years 1937 and 1948 (and unaffected directly by the reform), while holding any pre-reform cohort differences constant. Since the reform reduced the generosity of future pensions for the affected cohorts, we expect to observe an increase in saving and, if income remains unchanged, a decrease in expenditure.

In order to increase the precision of our results, we also include a vector of controls, denoted $x$, which includes month-of-year dummies, a quadratic polynomial in age, gender, number of children, marital status, education, a dummy for whether the head of household's spouse is younger, occupation dummies, a dummy for working in the private sector, and a dummy for whether the household owns the house it lives in. We do not include lifetime earnings on the right-hand side of Equation (1), as lifetime income is likely to be correlated with pension wealth and saving behavior. Instead, we use education and occupation dummies that serve as proxies for lifetime income. Since the analysis is conducted on the household level, all of the variables reflect the characteristics of the head of household.

In order to attribute a change in outcomes to the reform, our identifying assumption is that conditional on observables $x$, time effects $\alpha_{t}$, and cohort fixed effects $\alpha_{g}$, the time-by-cohort effects $\alpha_{t g}$ affect the outcomes because of the reform. Because we have two years of data

\footnotetext{
${ }^{12}$ Since we define the cohorts to span more than one year-of-birth cohort and we control for age effects by using a quadratic polynomial, this allows us to solve the "age-time-cohort" colinearity problem.
} 
preceding the reform, an indirect test of this assumption is to check for pre-intervention timeby-cohort effects. If the saving behavior of the cohorts affected by the reform differed already in the years before the reform, it calls into question whether our empirical strategy does indeed identify reform effects. As it turns out, we do not find evidence of pre-program timeby-cohort differences, suggesting that the difference-in-differences estimates can be interpreted as reform effects.

\subsection{Consequences of the reform: estimating the degree of public pension}

\section{crowd-out}

The reduced-form difference-in-differences regressions have the advantage of being transparent, but they are not informative of the degree of public pension crowd-out. In the next part of the analysis we move beyond the simple difference-in-differences approach and impose more structure on our analysis. In order to identify the main parameter of interest of this study, the degree of substitutability between private saving and public pension wealth, we need to relate the change in saving behavior to the change in expected pension wealth.

To do so, we estimate the following model:

$$
s r_{i t}=\theta\left(\frac{P W_{i t}}{y_{i t}}\right)+\alpha_{t}+\alpha_{g}+x_{i t} \beta+\epsilon_{i t}
$$

where $s r$ is household $i$ 's saving rate, and $\frac{P W_{i t}}{y_{i t}}$ equals a household $i$ 's expected pension wealth, divided by current household labor income. In our analysis, we correct $\frac{P W_{i t}}{y_{i t}}$ by a discrete-time version of “Gale’s Q" adjustment factor; see Appendix B for details (Gale 1998). The parameter of interest is given by the estimate $\theta$. If public pensions crowd out private household saving, we expect the estimate of $\theta$ to lie between -1 (complete crowd-out: private saving goes down by 1 unit for each additional unit of public pension wealth) and zero (no crowd-out) 
In addition to using the saving rate as an outcome variable, we also estimate models using the log of expenditure. If household income did not change differentially by group and time, we expect the relationship between pension wealth and log expenditure to be a mirror image of the relationship between pension wealth and saving rate.

Finally, we also study the reaction of saving in levels. When we use saving as the outcome variable, we do not normalize the expected pension wealth by household income. Instead, we estimate the regression saving $_{i t}=\theta P W_{i t}+\alpha_{t}+\alpha_{g}+x_{i t} \beta+\epsilon_{i t}$, so that both pension wealth and saving are expressed in levels as opposed to proportions.

Since individuals who tend to save more may have higher pension wealth because of different lifetime income trajectories or because of an unobserved "taste for saving," simply regressing the saving rate on pension wealth may introduce a positive bias in the estimate of $\theta$. At the same time, it is likely that pension wealth is measured with error, and this measurement error will bias the OLS estimate of $\theta$ toward zero. Finally, not accounting for differences in remaining planning horizons (that is, “Gale’s Q" adjustment factor) will also likely bias the estimate of $\theta$ towards zero. Together, measurement error and unobserved heterogeneity are likely to bias the OLS estimate of $\theta$ in opposite directions (see Alessie, Angelini, and van Santen [2013] for a discussion of measurement error and omitted variable bias problems in the context of pension crowd-out studies).

We correct this error-in-variables problem and identify the effect of pension wealth on saving rate by using the instrumental variables approach. We instrument pension wealth with the time-by-cohort interactions $\alpha_{t g}$, which are now excluded from the "second-stage" Equation (2) (see Meyer [1995], p. 159, for a discussion on combining instrumental variables and difference-in-differences studies). The "first-stage" regression can be summarized as follows:

$$
\frac{P W_{i t}}{y_{i t}}=\alpha_{t g}+\alpha_{t}+\alpha_{g}+x_{i t} \beta+v_{i t}
$$


Our identifying assumption is that, after controlling for observables $x$, time effects $\alpha_{t}$, and cohort fixed effects $\alpha_{g}$, the time-by-cohort interactions $\alpha_{t g}$ have no independent effect on household saving rate other than through pension wealth. The instrumental variable needs also to be relevant. The latter turns out to be easily fulfilled, as pension wealth strongly varies over time-by-cohort interactions. We discuss the validity of our study below.

\subsection{Validity of estimates}

External validity indicates the degree to which the conclusions from a study can be generalized to other populations and settings. Because the 1999 pension reform was a large reform on a nationwide scale, and because its segmented implementation bears a resemblance to a natural experiment, we believe the external validity of our study to be high.

At the same time, because our identifying variation stems from comparing households from various cohorts over time, this may present a potential threat to internal validity-i.e., the degree to which the 1999 pension reform is exogenous and the degree to which cohorts are comparable. For example, internal validity may be compromised if the reform was anticipated before 1997, thus leading households to adjust their behavior in advance. Another challenge arises if the cohorts studied differ in unobserved ways before and after the reform (for example, if there are unobserved factors that affect the difference in trends between cohorts), which would lead to a situation where there is correlation between the cohort-bytime dummies $\alpha_{t g}$ and the regression error term.

We think that the internal validity is reasonably high. First, the particulars of who would and who would not be affected by the 1999 pension reform were not decided upon before the fall of 1998. In consequence, this left little time for the affected cohorts to adjust their spending before the reform. Alternatively, it is conceivable that, in anticipation of the reform, households could have adjusted their labor supply. Lindner and Morawski (2012) use a 
regression-discontinuity design to compare the labor supply of the 1948 cohort to the labor supply of the 1949 cohort, but find no effect of the 1999 pension reform on labor market outcomes. We return to the discussion of anticipation effects in subsection 4.5, where we discuss robustness checks of our analysis.

Second, we deal with the challenge of comparing saving and spending behavior of cohorts of different ages across time by conditioning the regressions on age polynomials and other demographics. However, if unobserved heterogeneity across the cohorts before and after the reform remains, this may weaken our ability to identify the effect of the reform. Because of this, our identification is arguably stronger for the treated cohorts that are closer in age to the comparison cohort.

Finally, in order to use an instrumental variable to correct for measurement error in pension wealth, the time-by-cohort interactions cannot be correlated with the measurement error in pension wealth. However, measurement error in pension wealth, which is a function of lifetime earnings, might be a bigger concern for younger and better-educated households, since they are likely to face relatively better economic prospects in a transition economy.

\section{Results}

\subsection{Difference-in-differences results}

In Figure 2, we begin with a time series plot of average saving rate for the different cohorts across time. The saving rate is calculated as average household expenditure minus household income, divided by household income. Figure 2 shows the secular downward trend in Polish household saving rates across the 1990s. The graph shows that relative to 1998, in 1999 the saving rate tends to go up more for the cohorts affected by the reform than for the cohort unaffected by the reform. Next, we go beyond the simple time series plots and present the 
difference in saving rates of the affected cohorts relative to the unaffected cohort and relative to the pre-reform year 1998.

[Figure 2 here]

Figures 3, 4, and 5 present the point estimates from multiyear difference-in-differences regressions. Presenting the results visually allows us to detect signs of existing pre-reform cohort-by-time trends. In order to be able to interpret the point estimates as effects of the reform on behavior, we should not see any significant differences in any outcomes between the cohorts affected by the reform and the cohort unaffected by the reform in the years preceding the reform. This is a falsification-type test for the difference-in-differences model; see Angrist and Pischke (2009), pp. 237-241.

[Figures 3 and 4 here]

Figures 3 and 4 show point estimates from model (1) using saving rate and saving as outcome variables. In Figure 5, we estimate model (1) using log expenditure as the dependent variable. If the income available to the household has not changed differentially by cohort and time, we expect the reaction of expenditure to be the mirror image of the reaction of saving. All figures are plotted, along with 95 percent confidence intervals, across the pre- and post-reform years. The omitted time period in these plots is the immediate pre-reform year, 1998, and the omitted cohort is the comparison cohort, those born between 1937 and 1948 . The figures do not control for demographics, but as we show in Appendix C, the results are very similar when demographic controls are included.

[Figure 5 here]

In order to see whether it takes time for households to adjust their saving behavior (perhaps because of to "savings inertia”; see, e.g., Madrian and Shea [2001]), we present the results for four years following the reform (1999-2003). Although the results have the expected sign—-that is, saving (expenditure) tends to increase (decrease) over time for the 
affected cohorts in the post-reform years - the estimates are sometimes imprecise. In those cases, we are unable to detect statistically significant pre-reform differences in saving behavior between the affected and unaffected cohorts.

One interesting issue is which margin of saving behavior generates the estimated response in Figures 3 and 4: do more households save, or are households who save, saving more? From Table 3, we know that about 64 percent of the analysis sample saves a positive amount. Figure 6 shows point estimates from model (1), which uses a dummy variable that equals one if the household's saving is greater than zero and zero otherwise as an outcome variable. Figure 6 shows that there is no statistically significant response of saving along the extensive margin, which suggests that the pension reform induced those households already saving to save more.

[Figure 6 here]

Since the BBGD in 1997 collects expenditure categories on a more aggregate level than in the later years 1998-2003, only a few subcategories are comparable across all of the years. One of the subcategories we observe consistently across 1997-2003 is food expenditure. Figure 7 presents the point estimates from multiyear difference-in-differences regressions of log of food and non-alcoholic beverage expenditure. Since food and non-alcoholic beverage consumption are typically considered necessities, we would not expect households to cut back much on food expenses because of the reform. Indeed, the results in Figure 7 suggest that, for middle-aged and younger cohorts, compared to the reaction of total expenditure in Figure 5, the reaction regarding food expenditure was smaller and mostly not statistically different from zero. For older cohorts, we observe a less-than-10-percentage-point decrease. We can only speculate on why this is so, but perhaps this indicates that older households may reduce food expenditure by increasing food production and preparation at home (see Hurst 2008) or reduce expenditure by buying a different and cheaper basket of products. 
[Figure 7 here]

In summary, the magnitude of the estimated effects on saving rate in the post-reform years in Figure 3 is between 0 and 5 percentage points; this magnitude is, however, not informative of the degree of crowd-out. In order to ascertain the size of the response, we now turn to results from the model in Equation (2).

\subsection{The effect of pension wealth on saving and expenditure}

Table 4 shows the $\theta$-estimates from regressions using household saving rate, log expenditure, and saving in levels as outcome variables.

Panels A and B present coefficient estimates using simple OLS. In Panel A we use the unadjusted pension wealth, while in Panel B we use the "Q-adjusted” pension wealth. Results presented in Panel $\mathrm{C}$ instrument pension wealth with the time-by-cohort interaction using 2SLS. This interaction consists of a post-reform dummy taking on a value of one for all of the post-reform years (and zero otherwise) and three dummies taking on a value of one if the household belongs to one of the three cohorts directly affected by the reform (and zero if it belongs to a cohort unaffected by the reform). Hence, the number of variables used to instrument pension wealth equals three: 1) post-reform $\times$ older cohort, 2) post-reform $\times$ middle-aged cohort, and 3) post-reform $\times$ younger cohort, making our model overidentified.

[Table 4 here]

We do not report coefficients on other controls. These other variables include controls for month-of-year dummies, a quadratic polynomial in age, gender, number of children, marital status, education, a dummy for whether the head of household's spouse is younger, occupation dummies, a dummy for working in the private sector, a dummy for whether the household owns the house it lives in, a "post-reform" dummy, and three "affected cohort" dummies. 
In the OLS specifications using the unadjusted pension wealth (Panel A), the $\theta$-estimates are small, at times imprecise, and the estimated "effect" on log expenditure is of the unexpected sign: a marginal increase in pension wealth tends to decrease household spending. Panel B presents estimates of the effect of pension wealth on outcomes using the $Q$-adjusted pension wealth. Since the $Q$-factor rescales the pension wealth variable, the sign of the estimated $\theta$-coefficient does not change. The $Q$-factor adjustment magnifies the estimated coefficient in absolute terms.

In contrast, the 2SLS estimates in Table 4 (Panel C) are all of the expected sign and are larger in absolute terms. These crowd-out estimates suggest that a 1 PLN increase in pension wealth reduces the household's private saving by about 0.24 PLN (specification 7) or increases household spending by about 0.21 PLN (specification 8). Note that the absolute value of the crowd-out of saving and the absolute value of the crowd-in of expenditure are statistically not different from one another.

When we use saving in levels as the dependent variable, crowd-out is greater (about 0.57) than when we use saving rate as the dependent variable. This is in part because our definition of saving (monthly available income minus monthly expenditure) is negatively skewed, which might make simple average effects less informative. We have also estimated an instrumental-variable (IV) quantile regression (QR) using saving as the dependent variable. We find that, at the median (not shown), the IV-QR estimate of crowd-out is about 0.36, which is much closer to the mean estimates of crowd-out in cells (7) and (8) in Table $4 .{ }^{13}$ For this reason, our preferred estimates are those using saving rate and the logarithm of expenditure.

The row labeled IV F-statistic shows the statistic from the F-test of relevance of the instrumental variable. We see no indication of a weak instrument problem. Below the F-

\footnotetext{
${ }^{13}$ Also, when using expenditure in levels, the crowd-in estimates are greater in absolute value than when we use the logarithm of expenditure as our dependent variable, where the latter is approximately normally distributed. These results are available upon request.
} 
statistic, we report $p$-values from a $J$-test for overidentification. For saving and saving rate, the $J$-test $p$-value is well above any conventional significance level; however, for log expenditure the test gives a low p-value, which may suggest heterogeneity in treatment effects across cohorts. We study this issue in the next subsection.

Since the model is overidentified, following Angrist and Pischke’s (2009, pp. 205-216) suggestion, in Panel $\mathrm{D}$ we also present estimates using a limited information maximum likelihood (LIML) model. The coefficients change only slightly, which suggests that the degree of overidentification is not problematic.

\subsection{Measurement error and unobserved taste for saving}

The change in sign between the OLS and 2SLS estimates in Table 4 is consistent with measurement error in pension wealth combined with unobserved heterogeneity in the propensity to save. Recall that classical measurement error in pension wealth will bias the $\theta$ coefficient toward zero, but it will not change the direction of the correlation between pension wealth and saving. On the other hand, if the unobserved propensity to save and pension wealth are positively correlated, then unobserved heterogeneity in the propensity to save may introduce an upward bias in the $\theta$-estimate. Since measurement error and unobserved heterogeneity are likely to bias the $\theta$-coefficient in opposite directions, we can only infer the extent of the combined bias by observing how the OLS estimates differ from the 2SLS estimates.

The change in the results in Table 4 suggests a substantial unobserved variable bias in OLS estimates. This is not unexpected, as in going from OLS to 2SLS, Attanasio and Rohwedder (2003) (see Tables 4 and 5 in their paper) report a similar change in the magnitude of their estimated crowd-out effect. Similarly, using OLS, Engelhardt and Kumar 
(2009) find a positive $\theta$-coefficient that equals 0.23 , while, when using 2SLS, the $\theta$ coefficient changes to -0.53 .

\subsection{Analysis by subsamples}

Economic theory suggests that those who are at a late point in their life cycle will react the strongest to the decrease in pension wealth, as they have a relatively short time horizon in which to adjust their behavior. Also, previous research studying the effects of pension wealth on household saving often finds heterogeneous responses among older and younger households (see Gale [1998] and Attanasio and Brugiavini [2003]). In order to understand whether the estimated effects are concentrated among a specific cohort, Table 5 presents the 2SLS results separately for the three cohorts affected by the reform, in relation to the unaffected cohort.

For each dependent variable (saving rate, log of expenditure, and saving), we "net out" the effect of demographics (including age and its square) by regressing each dependent variable on the vector of observables, $x$, and saving the residual. ${ }^{14}$ Then, for each cohort affected by the reform, we estimate a separate 2SLS model using the comparison cohort and the affected cohort. In each column, we regress the residualized outcome variable on a "postreform" dummy and an "affected cohort" dummy. The model is just-identified using the dummy "post-reform" interacted with a dummy for "affect cohort" as the excluded instrumental variable.

Table 5 shows that the crowd-out is the biggest in absolute terms for the older and middle-aged cohorts. For the middle-aged cohort, the crowd-out estimate of the saving rate and the crowd-in estimate for spending show that each additional PLN in pension wealth reduces saving by about 0.45 PLN and increases spending by about 0.54 PLN. When using

\footnotetext{
${ }^{14}$ The $x$ vector consists of month-of-year dummies, a quadratic polynomial in age, gender, number of children, marital status, education, a dummy for whether the head of household's spouse is younger, occupation dummies, a dummy for working in the private sector, and a dummy for whether the household owns the house it lives in.
} 
saving rate as the dependent variable, the crowd-out estimate for the older cohort is more imprecise, but overall it suggests large crowd-out. For the younger cohort, we observe that the crowd-out is smaller in absolute value: the crowd-out effect is about 0.29 when using saving rate as the dependent variable, and the crowd-in is about 0.18 for household expenditure. On the one hand, this is consistent with the interpretation that this cohort has a longer horizon over which to increase saving and reduce spending relative to the older cohort and therefore does not react as strongly. On the other hand, the comparison of the younger cohort affected by the reform to the unaffected cohort might not identify the crowd-out effect as credibly as the comparison of affected cohorts closer in age to the unaffected cohort.

\section{[Table 5 here]}

Below each coefficient, the row labeled IV F-statistic shows the statistic from the F-test of relevance of the instrumental variable. Again, for each of the just-identified models, we do not detect a weak instrument problem.

Previous research on financial literacy has found that households may not understand how pension systems work. One might speculate that people with a college degree might be better informed about pension systems in general and aware of how a pension reform might affect them. If so, we would expect the crowd-out effect for highly educated households to be larger in absolute value. Bottazzi, Jappelli, and Padula (2006), for example, find a crowd-out of about 0.80 among individuals informed about pension systems. Also, better-educated households might be “active” savers (Chetty et al. [2014]) or, compared to less-educated households, they might have more capacity to adjust their savings. Gale (1998), for example, finds a crowd-out of close to 0.70 for highly educated households. We do not have direct measures of how financially literate a household is, and so we estimate crowd-out separately for households where the head reports having at least tertiary (that is, college) education. 
Theory also suggests that households that have accumulated enough buffer stock might not be as sensitive to pension wealth changes as those without assets. For the years we are considering, the BBGD does not include information about financial assets, but it does include data on whether the household owns the house or apartment in which it lives.

Table 6 presents the 2SLS estimates of crowd-out for different types of households: the top panel shows the estimate of $\theta$ for households where the head has at least tertiary education and where the head of households has less than tertiary education. The lower panel shows the estimates for households that do and do not own their place of residence.

\section{[Table 6 here]}

For households where the head has at least tertiary education, Table 6 shows a complete crowd-out when using saving and saving rate and a large crowd-in when using log expenditure as an outcome variable. These 2SLS estimates are larger in absolute value than the 2SLS estimates from Table 4. Turning to households where the head of household does not have a tertiary education, we see that the crowd-out equals about 0.14 using saving rate as an outcome and about 0.40 when using saving in levels as an outcome.

For household that do not own their place of residence, we find a larger point estimate of expenditure crowd-in than for households that do, but overall this set of estimates is less precise.

\subsection{Sensitivity checks}

In this section we present sensitivity checks of our main results. We begin by studying the sensitivity of the estimated $\theta$-coefficient to assumptions regarding the subjective discount factor, $\beta$. If households do not put much weight on the future, i.e., if $\beta$ is low, we expect the crowd-out estimate to be small. In contrast, if households are patient, we expect a larger crowd-out. 
In Figure 8, we plot the 2SLS estimates of $\theta$ as a function of $\beta$, where we let $\beta$ vary from 0.90 to $0.999 .{ }^{15}$ Note that the literature on public pension crowd-out either sets the subjective discount factor to equal 0.96 (Gale 1998), 0.97 (Alessie, Angelini, and van Santen 2013), or 0.98 (Attanasio and Brugiavini 2003; Attanasio and Rohwedder 2003; Bottazzi, Jappelli, and Padula 2006; Feng, He, and Sato 2011).

[Figure 8 here]

Two points are worth noting with respect to Figure 8. First, the estimated relation between $\theta$ and $\beta$ is not linear. For values of $\beta$ between 0.90 and 0.95 , the crowd-out is estimated to be around zero. Starting at $\beta=0.96$, the estimated crowd-out equals 0.10 and, as $\beta$ approaches one, the crowd-out increases to about 0.40 . Second, in general, the crowd-out estimated using saving in levels as the outcome variable is greater than when using the other dependent variables, likely because of its skewed distribution. This difference is the greatest when $\beta$ is equal to our benchmark value, 0.98 .

Tables 7 and 8 present other robustness checks.

\section{[Table 7 here]}

In Table 7, we re-estimate the main model using two alternative analysis samples. First, we re-estimate the model from Table 4, but this time without the year 1997. We do so because the design of the BBGD in 1997 with respect to expenditure categories was different from the one in years 1998-2003. By dropping the year 1997 and using 1998 as the only prereform year, we want to ensure that our interpretation of our main results is robust. By dropping the year 1997, the size of our comparison group shrinks, and this reduces the precision of our crowd-out estimates. When comparing the crowd-out estimate from Table 7 (specification 1) to the preferred crowd-out estimate from Table 4 (where it is estimated to be 0.24 using saving rate as the outcome variable), we see that the point estimates remain

\footnotetext{
${ }^{15}$ In order to plot the estimates effects on the same scale, when we use the log expenditure as the dependent variable, we change the sign of $\theta$.
} 
similar-the crowd-out in Table 7 is estimated to be around 0.22 . When using log of expenditure, $\theta$ equals approximately 0.14 but is imprecise. Next, we restrict our analysis sample to include only 18 - to 60 -year-old males and 18- to 55-year-old females. We do this so that the analysis sample excludes households closer to the retirement age that may have anticipated the reform. The results in Table 7 (specification 2) are similar to the main results in Table 4, with $\theta$ estimated to be around -0.23 when using saving rate as the outcome variable and 0.21 when using log expenditure as the outcome variable.

[Table 8 here]

In Table 8, we keep the analysis sample fixed but conduct several robustness checks regarding the assumptions made in Appendix A. First, we pool together the older and middleaged cohort into a big "transition” cohort and re-estimate Equation (2); the estimates are very similar to the 2SLS estimates in Table 4. Second, when calculating the pension wealth, we change the assumption regarding retirement age for men and for women: we assume that men retire at 55 years of age (instead of at 60 as in Table 4) and women retire at 50 (instead of at 55 as in Table 4). Again, the results are very similar to those in Table 4. Third, we change the assumption regarding women's employment pattern and re-calculate pension wealth under the assumption that women work and contribute to the pension system for 10 years (as opposed to 20 as in Table 4). Again, the results are similar to Table 4, although, for log expenditure, they are less precise. Finally, we re-estimate the model where women's lifetime earnings projections are estimated without using a labor force participation selection model. This last specification uses simple OLS to forecast women's earnings. Again, the estimates of crowd-out are similar to the baseline estimate in Table 4. 


\section{Discussion}

Our difference-in-differences results show three things. First, the reform had a positive causal effect on increasing household saving and decreasing expenditure. Second, the decrease in expenditures was not driven by a change in the consumption of necessities, such as food and drink, at least for the middle and younger cohorts. Third, the reaction of saving was not driven by an increase along the extensive margin of saving, implying that the reform induced "savers" to save more.

The 2SLS analysis estimates that public pension crowds out private saving by about 0.24 PLN for each 1 PLN. This is a sizable, although far from complete, crowd-out. Subsample analysis reveals that this effect is concentrated among certain types of households, while other households do not adjust their saving to changes in pension wealth.

For the older and middle-aged cohorts, we find a large and statistically significant crowdout ranging between 0.45 and complete crowd-out. This, combined with Lindner and Morawski's (2012) results, suggests that, when faced with a reduction in future pension benefits, older households in Poland choose to adjust their saving rather than labor supply. We also find that highly educated households-households we expect to be informed about the reform or who are financially more able to adjust—exhibit a complete crowd-out.

Younger households and lower-educated households display much smaller public pension crowd-out. We speculate that the modest response among these households could be due to liquidity constraints, incomplete information, or uncertainty about how enduring the 1999 reform would be. The observed passive behavior of less-educated households echoes the findings of the literature on financial literacy, which finds that by remaining passive, these households are at risk of being inadequately prepared for retirement. One policy recommendation emerging from this is the need for a comprehensive approach to improvements in financial literacy in order to educate the population at risk about the 
importance of financial planning. Alternatively, policy-makers might consider the role of defaults on household behavior or the use of paternalistic "nudges" as a policy substitute for expanding financial literacy to push passive households to adjust their saving (Messacar 2014).

How do our estimates relate to the existing literature on public pension crowd-out of private savings? On the one hand, our estimate of 0.24 , when compared to other recent studies, is at the lower end of the range of existing estimates. ${ }^{16}$ On the other hand, we show that the estimates of crowd-out depend to a degree on the assumptions that researchers make about the subjective discount rate of households. For example, our main crowd-out estimate of 0.24 assumes that the discount rate equals 2 percent. Assuming instead a lower discount rate-i.e., assuming that the household is more patient-yields a crowd-out closer to 0.40 . Clearly, this difference is not trivial and carries implications for policy. In order for researchers to make recommendations about the impact of public pensions on saving, we need to know more about the subjective discount rates and how to model them.

\section{Conclusions}

This paper studies the large change in expected pension wealth induced by Poland's 1999 pension reform to estimate the effect public pensions have on household saving. The implementation of the reform created quasi-experimental variation in pension wealth suitable for investigating whether public pensions depress household saving. We find that public pensions crowd out private saving by 0.24 PLN per 1 PLN and that this effect is strongest for highly educated households and older households. For these groups of households, we find that public pension and private saving are close to perfect substitutes. In contrast, for the

\footnotetext{
${ }^{16}$ Gale (1998) estimates the crowd-out to be 0.50; Attanasio and Brugiavini (2003) report a range of effects between 0.30 and 0.70; Attanasio and Rohwedder (2003) report the crowd-out to be between 0.65 and 0.75 ; Bottazzi, Jappelli, and Padula (2006) estimate it to be 0.70; Aguila (2011) reports it to be 0.50; and Feng, He, and Sato (2011) estimate it to be between 0.10 and 0.16 .
} 
young and less-educated, the crowd-out is less than one-for-one. For the young, building up a stock of wealth could perhaps be a question of time. However, our results suggest that the less-educated households, who remain passive to decreases in pension benefits, either because of liquidity constraints or from an inability to accurately process economic information, are at risk of having a low standard of living in retirement. One important policy conclusion of this study is that limited financial literacy should be taken into consideration when designing pension reforms. 


\section{References}

Aguila, E. 2011. "Personal Retirement Accounts and Saving.” American Economic Journal: Economic Policy 3(4): 1-24.

Alessie, R., V. Angelini, and P. van Santen. 2013. "Pension Wealth and Household Savings in Europe: Evidence from SHARELIFE.” European Economic Review 63(October): 308-328.

Alessie, R., A. Kapteyn, and F. Klijn. 1997. "Mandatory Pensions and Personal Savings in the Netherlands.” De Economist 145(3): 291-324.

Angrist, J., and J.-S. Pischke. 2009. Mostly Harmless Econometrics: An Empiricist’s Guide. Princeton, NJ: Princeton University Press.

Attanasio, O., and A. Brugiavini. 2003. “Social Security and Households’ Saving.” Quarterly Journal of Economics 118(3): 1075-1119.

Attanasio, O., and S. Rohwedder. 2003. "Pension Wealth and Household Saving:

Evidence from Pension Reforms in the United Kingdom.”American Economic Review 93(5): 1499-1521.

Banerjee, S. 2011. "Does Social Security Affect Household Saving?” In Essays in Economics of Aging, PhD dissertation. Columbus, OH: Ohio State University, pp. 564.

Bargain, O., L. Morawski, M. Myck, and M. Socha. 2007. “As SIMPL as That: Introducing a Tax-Benefit Microsimulation Model for Poland.” IZA Discussion Paper No. 2988. Bonn, Germany: Institute for the Study of Labor.

Barlik, M., and K. Siwiak. 2011. Metodologia Badania Budżetów Gospodarstw Domowych" Warsaw, Poland: Główny Urząd Statystyczny-Departament Warunków Życia.

Bernheim, D. 1987. "The Economic Effects of Social Security: Toward a Reconciliation of Theory and Measurement.” Journal of Public Economics 33(3): 273-304.

2002. “Taxation and Savings.” In A. Auerbach and M. Feldstein (eds.), Handbook of Public Economics. Vol. 3. Amsterdam: Elsevier, pp. 1173-1249.

Bottazzi, R., T. Jappelli, and M. Padula. 2006. "Retirement Expectations, Pension Reforms, and Their Impact on Private Wealth Accumulation.” Journal of Public Economics 90(12): 2187-2212.

Brugiavini, A., K. Maser, and A. Sundén. 2005. “Measuring Pension Wealth.” Unpublished paper, University of Venice, Statistics Canada, and the Pension Board of Sweden.

Cagan, P. 1965. "The Effect of Pension Plans on Aggregate Saving: Evidence from a Sample Survey.” NBER Occasional Paper No. 95. Cambridge, MA: National Bureau of Economic Research. 
Chetty, R., J. Friedman, S. Leth-Petersen, T. Nielsen, and T. Olsen. 2014. “Active vs. Passive Decisions and Crowd-Out in Retirement Savings Accounts: Evidence from Denmark.” Quarterly Journal of Economics 121(4): 1311-1346.

Chłoń-Domińczak, A. 2002. “The Polish Pension Reform of 1999.” In E. Fultz (ed.), Pension Reform in Central and Eastern Europe. Vol. 1, Restructuring with Privatization: Case Studies of Hungary and Poland. Budapest: International Labour Office, pp. 95-205.

Chłoń A., M. Góra, and M. Rutkowski. 1999. "Shaping Pension Reform in Poland: Security through Diversity.” World Bank Social Protection Discussion Paper Series No. 9923. Washington, DC: World Bank.

Chłoń-Domińczak, A., and P. Strzelecki. 2013. "The Minimum Pension as an Instrument of Poverty Protection in the Defined Contribution Pension System: An Example of Poland.” Journal of Pension Economics and Finance 12(3): 326-350.

Engelhardt, G. V., and A. Kumar. 2011. "Pensions and Household Wealth Accumulation." Journal of Human Resources 46(1): 203-236.

Feldstein, M. 1974. "Social Security, Induced Retirement, and Aggregate Capital Accumulation.” Journal of Political Economy 82(5): 905-926.

Feldstein, M., and A. Pellechio. 1979. "Social Security and Household Wealth Accumulation: New Microeconometric Evidence.” Review of Economics and Statistics 61(3): 361368.

Feng, J., L. He, and H. Sato. 2011. "Public Pension and Household Saving: Evidence from Urban China.” Journal of Comparative Economics 39(4): 470-485.

Gale, W. G. 1997. "Effect of Social Security Reform on Private and National Saving." In Steven A. Sass and Robert K. Triest (eds.), Social Security Reform: Links to Saving, Investment, and Growth. Boston: Federal Reserve Bank of Boston, pp. 103-142.

1998. “The Effects of Pension on Household Wealth: A Reevaluation of Theory and Evidence.” Journal of Political Economy 106(4): 706-723.

2005. "The Effect of Pensions and 401(k) Plans on Household Saving and Wealth.” In W. G. Gale, J. B. Shoven, and M. J. Warshawsky (eds.), The Evolving Pension System: Trends, Effects, and Proposals for Reform. Washington, DC: Brookings Institution Press, pp. 103-122.

Gale, W. G., and J. K. Scholz. 1994. "IRAs and Household Savings.” American Economic Review 84(5): 1233-1260.

Gustman, A. L., and T. L. Steinmeier. 2005. "Imperfect Knowledge of Social Security and Pensions.” Industrial Relations 44(2): 373-397.

Hausner, J. 2002. “Poland: Security through Diversity.” In M. Feldstein and H. Siebert (eds.), Social Security Pension Reform in Europe, pp. 349-364. Chicago: University of Chicago Press, pp. 349-364. 
Holzmann, R., E. Palmer, and D. Robalino (eds.). 2012. Nonfinancial Defined Contribution Pension Schemes in a Changing Pension World. Vol. 1, Progress, Lessons, and Implementation. Washington, DC: World Bank.

Hubbard, G. R. 1986. "Pension Wealth and Individual Saving: Some New Evidence.” Journal of Money, Credit, and Banking 18(2): 167-178.

Hurd, M., P.-C. Michaud, and S. Rohwedder. 2012. "The Displacement Effect of Public Pensions on the Accumulation of Financial Assets.” Fiscal Studies 33(1): 107-128.

Hurst, E. 2008. “The Retirement of a Consumption Puzzle.” NBER Working Paper No. 13789. Cambridge, MA: National Bureau of Economic Research.

Katona, G. 1965. Private Pensions and Individual Saving. Survey Research Center Monograph No. 40. Ann Arbor, MI: University of Michigan Press.

King, M. A., and L.-D. L. Dicks-Mireaux. 1982. “Asset Holdings and the Life-Cycle.” Economic Journal 92(366): 247-267.

Lindner, A., and L. Morawski. 2012. “The Effect of Contribution-Benefit Link on Labor Supply: Evidence from the Polish NDC Scheme.” Unpublished paper, University of California, Berkley and University of Warsaw.

Lusardi, A., and O. S. Mitchell. 2014. "The Economic Importance of Financial Literacy: Theory and Evidence.” Journal of Economic Literature 52(1): 5-44.

Madrian, B. C. and D.F. Shea 2001. The Power of Suggestion: Inertia in 401(k) Participation and Savings Behavior. Quarterly Journal of Economics 116(4): 1149-1187.

Messacar, D. 2014. "The Crowd-Out Effects and Welfare Implications of Retirement Savings Nudges.” Unpublished manuscript, University of Toronto, Department of Economics, Toronto.

Meyer, B. D. 1995. “Natural and Quasi-Experiments in Economics.” Journal of Business and Economic Statistics 13(2): 151-161.

Munnell, A. H. 1976. “Private Pensions and Savings: New Evidence.” Journal of Political Economy 84(5): 1013-1032.

Organization for Economic Co-operation and Development (OECD). 2010. OECD Factbook 2010: Economic, Environmental, and Social Statistics. Paris: OECD.

Perraudin, W., and T. Pujol. 1994. "Framework for the Analysis of Pension and Unemployment Benefit Reform in Poland.” IMF Staff Papers 41(4): 643-674.

Pozo, S., and S. A. Woodbury. 1986. "Pensions, Social Security, and Asset Accumulation.” Eastern Economic Journal 12(3): 273-281. 
Venti, S. F., and D. A. Wise. 1990. "Have IRAs Increased U.S. Saving? Evidence from the Consumer Expenditure Survey.” Quarterly Journal of Economics 105(3): 661-698.

Yang, T.-T. 2014. "The Effect of Private Pensions on Household Saving: Evidence from Mandatory Employer-Provided Pension Reform.” Unpublished paper, University of British Columbia, Vancouver, BC. 


\section{Results}

Figure 1: Median replacement rate before and after the pension reform, by cohort

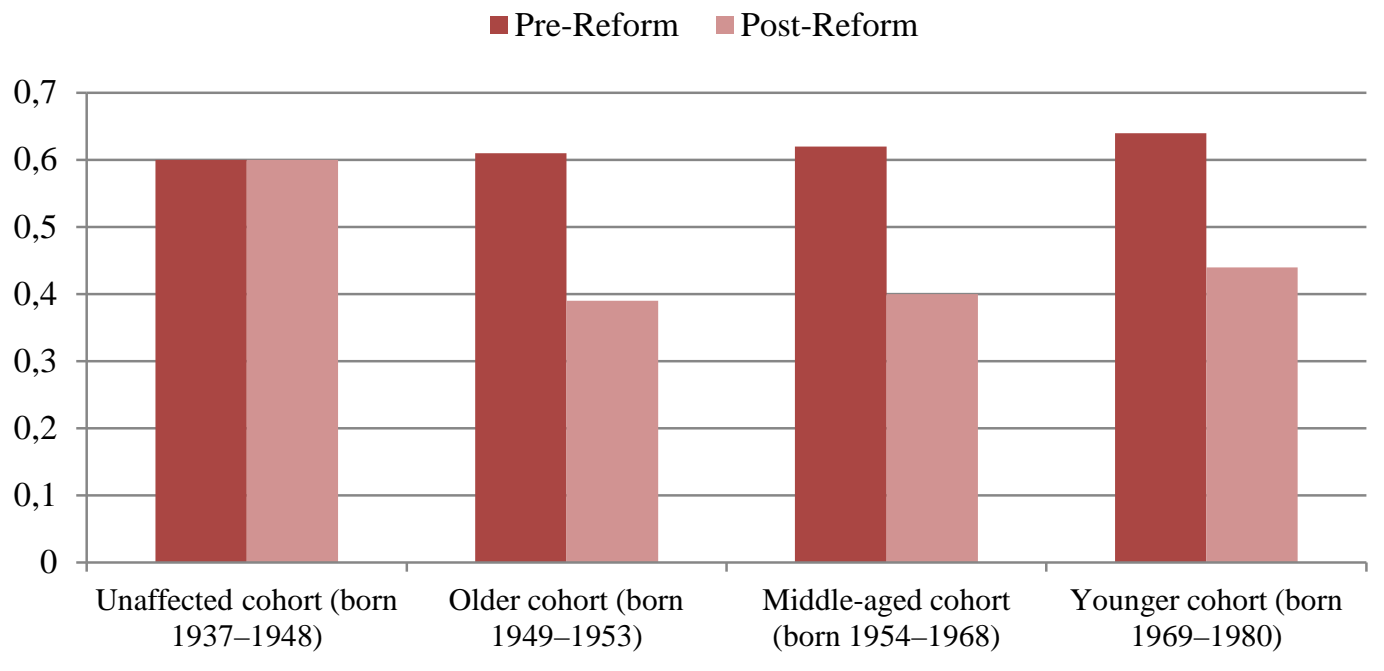

SOURCE: Author's calculations using BBGD 1998 and 1999.

NOTE: Replacement rate is defined as the ratio of first gross pension benefit to last gross salary of the head of the household. 
Figure 2: Saving rate in the BBGD, by year and cohort

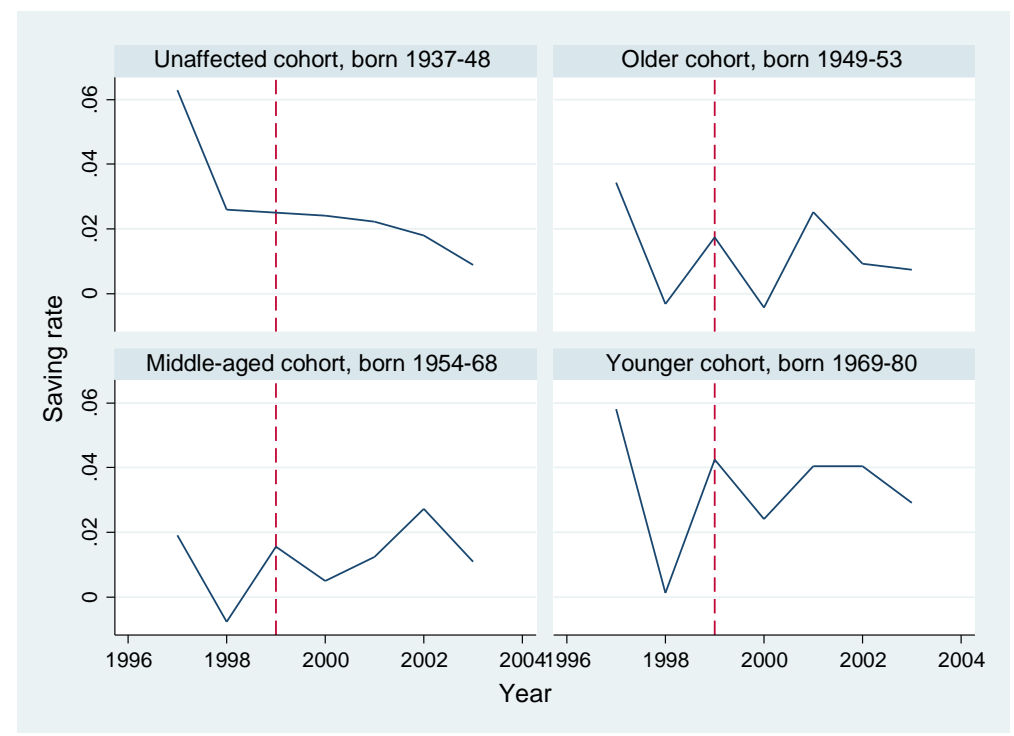

NOTE: Author's calculations using the BBGD 1997-2003. Saving rate is defined as average expenditure minus average labor income divided by labor income. The dashed vertical line indicates the first year of the reform.

Figure 3: Estimated effect of the 1999 pension reform on saving rate, by cohort

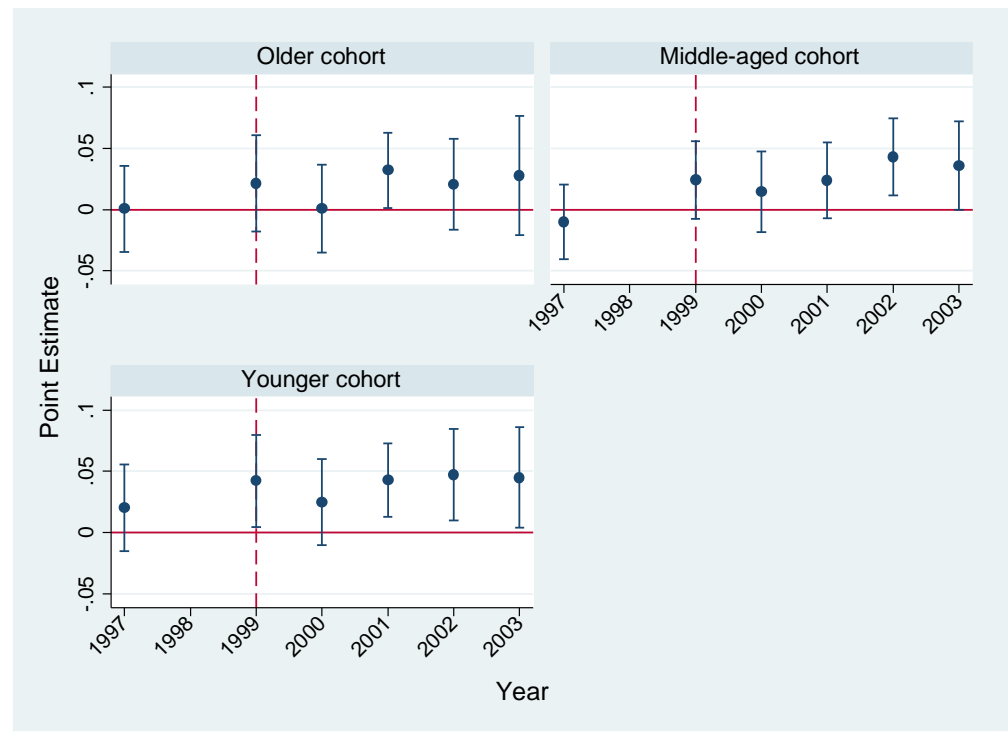

NOTE: The figure above shows point estimates from a multiyear difference-in-differences regression of saving rate on three cohort dummies (older cohort, born 1949-1953; middle-aged cohort, born 1954-1968; and younger cohort, born 1969-1980), six year dummies, and cohort-by-year interaction terms. For each cohort, each panel presents the cohort-by-year interaction point estimate over time. The omitted categories are Year 1998 (the year before the reform) and the cohort born 1937-1948 (the cohort unaffected by the reform). The regression uses robust standard errors clustered by year of birth, and the figure presents 95 percent confidence intervals. The dashed vertical line indicates the first year of the reform. 
Figure 4: Estimated effect of the 1999 pension reform on saving (in levels), by cohort

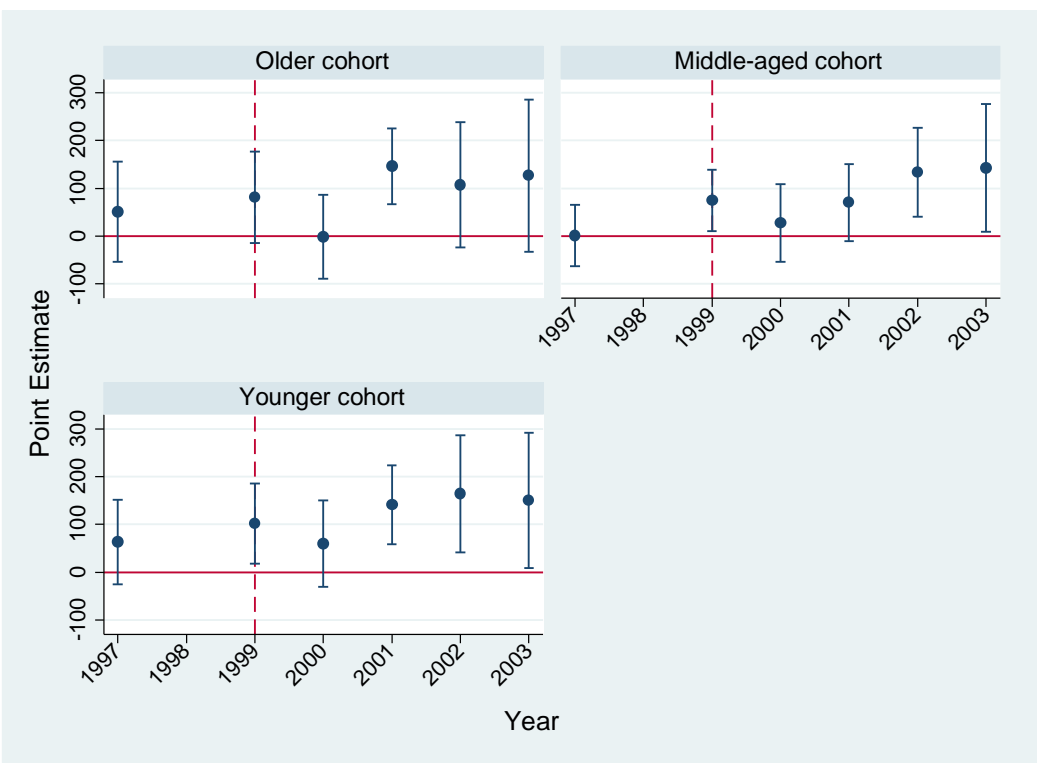

Figure 5: Estimated effect of the 1999 pension reform on log expenditure, by cohort

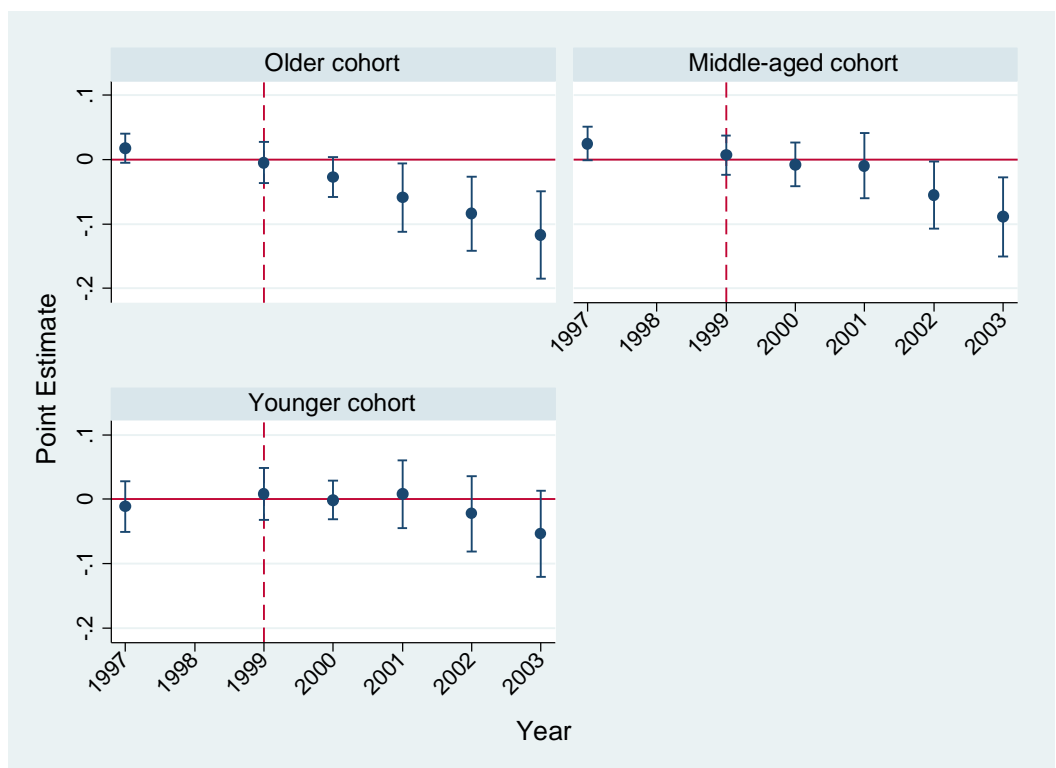

NOTE: Figures 4 and 5 show point estimates from a multiyear difference-in-differences regression of saving (top) and log expenditure (bottom) on three cohort dummies (older cohort, born 1949-1953; middle-aged cohort, born 1954-1968; and younger cohort, born 1969-1980), six year dummies, and cohort-by-year interaction terms. For each cohort, each panel presents the cohort-by-year interaction point estimate over time. See Figure 3 for further annotations. 
Figure 6: Estimated effect of the 1999 pension reform on the extensive margin of saving, by cohort

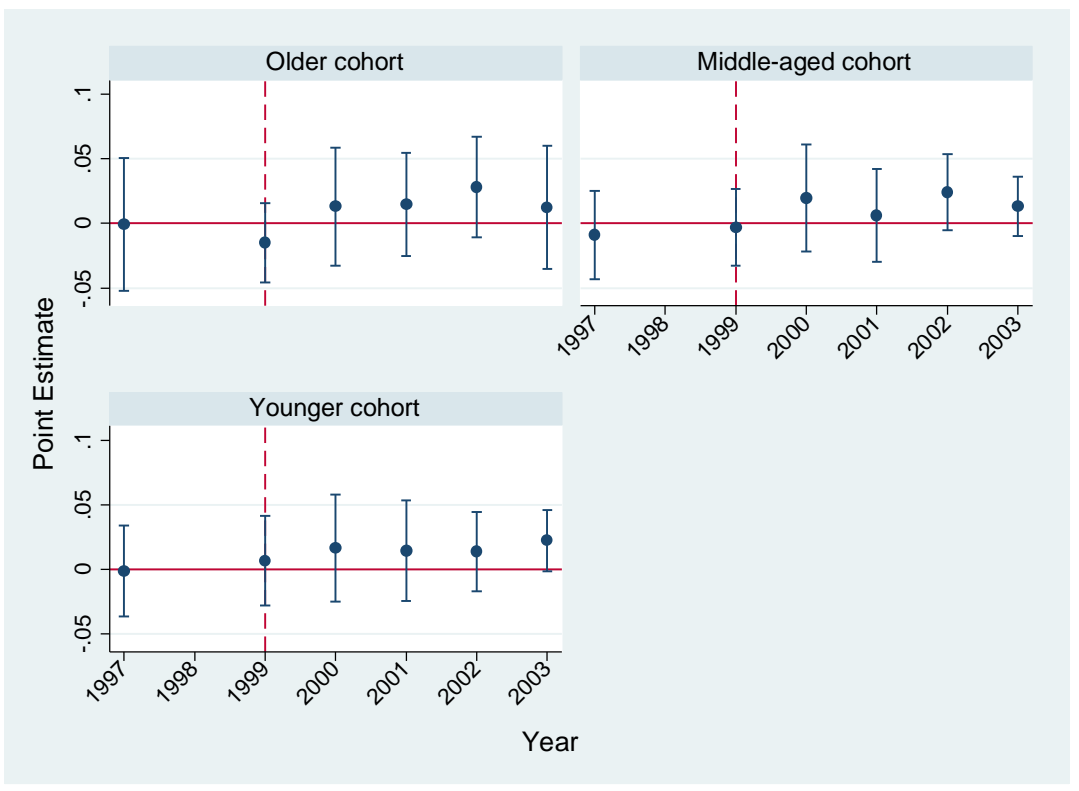

NOTE: Figure 5 shows point estimates from a multiyear difference-in-differences regression of a dummy of household being observed with positive savings on three cohort dummies (older cohort, born 1949-1953; middle-aged cohort, born 1954-1968; and younger cohort, born 1969-1980), six year dummies, and cohort-byyear interaction terms. For each cohort, each panel presents the cohort-by-year interaction point estimate over time. See Figure 3 for further annotations.

Figure 7: Estimated effect of the 1999 pension reform on log food and non-alcoholic beverage expenditure, by cohort

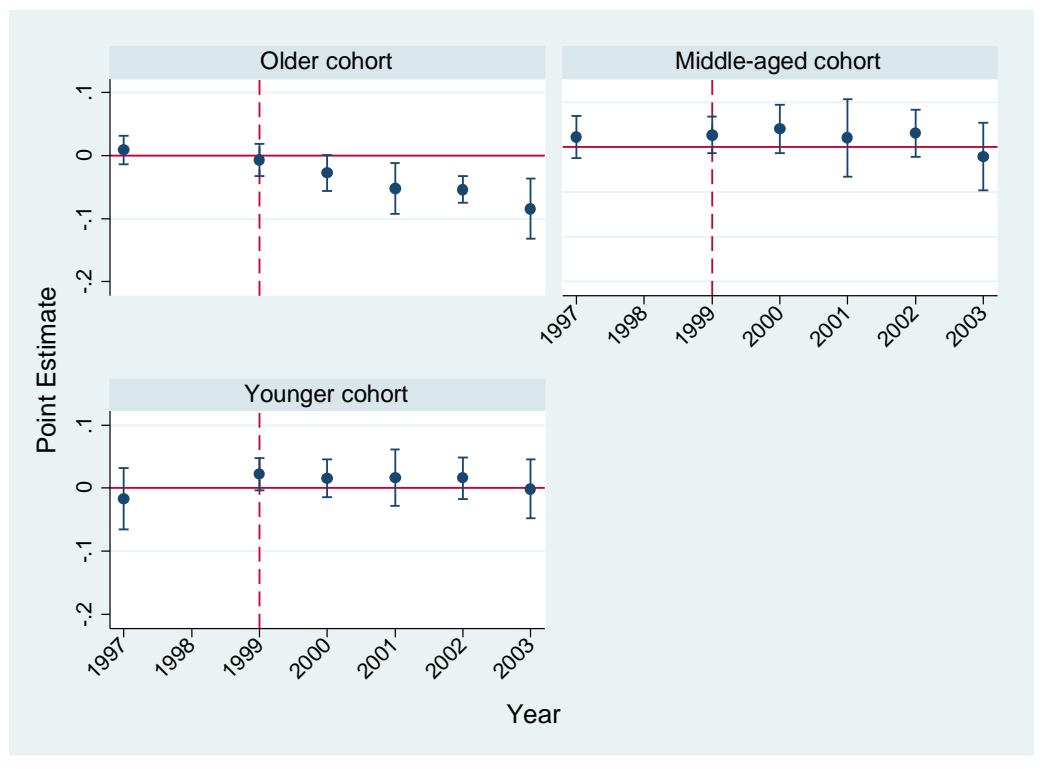

NOTE: Figure 6 shows point estimates from a multiyear difference-in-differences regression of log food and non-alcoholic beverage expenditure on three cohort dummies (older cohort, born 1949-1953; middle-aged cohort, born 1954-1968; and younger cohort, born 1969-1980), six year dummies, and cohort-by-year interaction terms. For each cohort, each panel presents the cohort-by-year interaction point estimate over time. See Figure 3 for further annotations. 
Figure 8: Robustness check: 2SLS crowd-out estimates of pension wealth as a function of the subjective discount factor

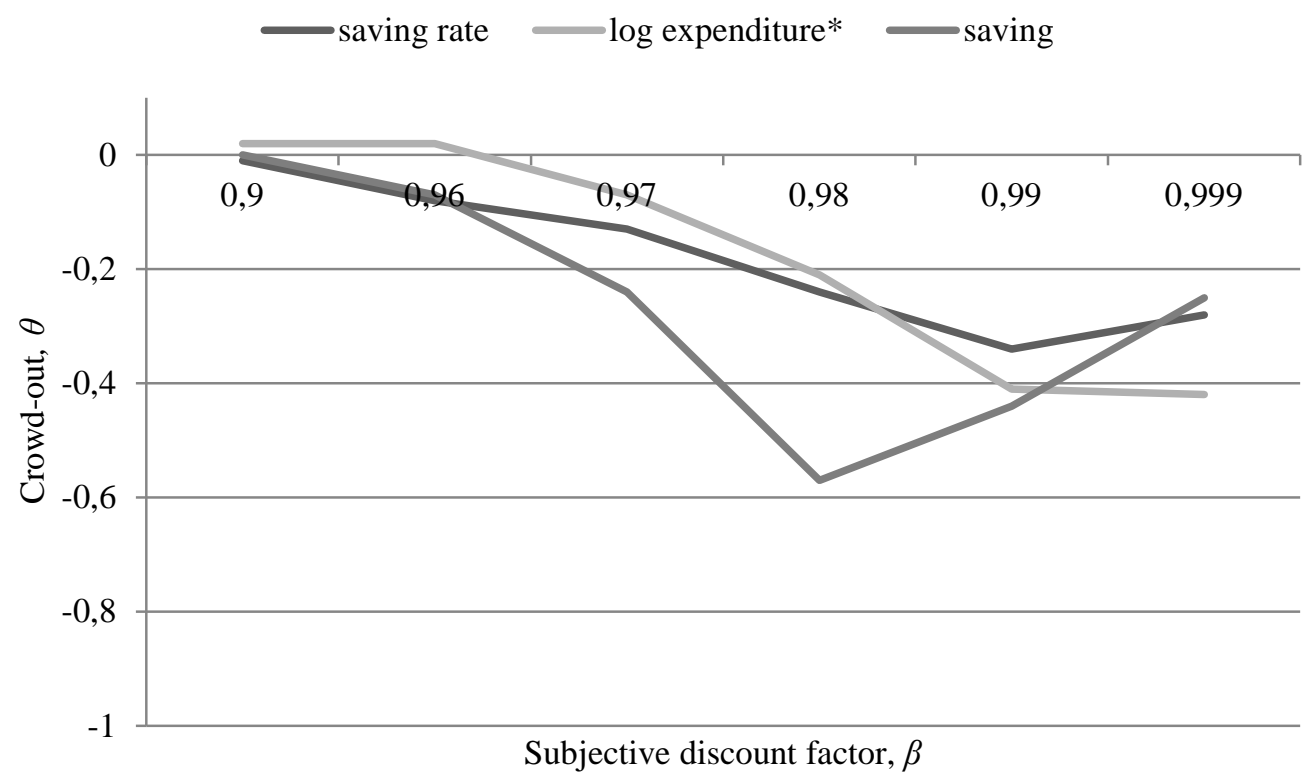

NOTE: Figure 8 shows point estimates from estimating pension crowd-out, $\theta$, using various assumptions regarding the subjective discount factor, $\beta$. The benchmark specification is $\beta=0.98$.

*To ease comparability, the estimations using log expenditure as an outcome have the reverse sign in Figure 8 than in the regression output. 
Table 1: Some main features of Poland's 1999 pension reform

\begin{tabular}{|c|c|c|}
\hline & $\begin{array}{l}\text { Pre-reform system, before } \\
1999\end{array}$ & $\begin{array}{l}\text { Post-reform system, since } 1999 \\
\text { (steady state) }\end{array}$ \\
\hline \multicolumn{3}{|l|}{ Financing and contributions } \\
\hline Financing & Pay-as-you-go, defined benefit. & $\begin{array}{l}\text { Pay-as-you-go, notionally defined } \\
\text { contribution (NDC) plan (1st tier) } \\
\text { and a funded defined contribution } \\
\text { (FDC) plan (2nd tier). NDC } \\
\text { contribution is } 12.22 \% \text { of salary, } \\
\text { FDC is } 7.3 \% \text {. }^{\text {a }}\end{array}$ \\
\hline \multicolumn{3}{|l|}{ Benefit calculation } \\
\hline Benefit formula & $\begin{array}{l}\text { Flat rate and an earnings- } \\
\text { related component. }\end{array}$ & $\begin{array}{l}\text { Actuarially adjusted and annuity- } \\
\text { based on total contributions. }\end{array}$ \\
\hline Pension base & $\begin{array}{l}\text { Average of } 10 \text { best years out of } \\
20 \text { years prior to retirement. }\end{array}$ & Lifetime earnings. \\
\hline Min. years of contributions & 20 for women, 25 for men. & 20 for women, 25 for men. \\
\hline Min. (and max.) pension benefit & $\begin{array}{l}35 \% \text { of average national wage. } \\
\text { (Max. earnings-related benefit: } \\
250 \% \text { of average national } \\
\text { wage). }\end{array}$ & $\begin{array}{l}20 \% \text { of average national wage. (Max. } \\
\text { contribution: } 250 \% \text { of average } \\
\text { national wage.) }\end{array}$ \\
\hline Retirement age & & \\
\hline
\end{tabular}

\section{Normal retirement age}

Early retirement provision

Transition rules
Because of early retirement options, the effective retirement ages: 59 for men, 55 for women.

Available for most occupations.

Cohorts born before 1949 are fully in the pre-reform system, including the right to retire early as in the pre-reform system.
65 for men, 60 for women. Certain groups, women, and workers
in the public sector, still have early retirement privileges.

Cohorts born after 1969 are fully in the new system. Cohorts born between 1949 and 1968 could choose to only contribute to the NDC part. ${ }^{\mathrm{c}}$ Separate rules for the first five cohorts of women affected by the reform (born 1949-1953).

$40-60 \%$ for men, $30-50 \%$ for women.

Replacement rate at 65 yrs. (men) and

65-76\% for men, $70 \%$ for women.

NOTE: Adapted from Chłoń, Góra, and Rutkowski (1999) and Chłoń-Domińczak (2002).

${ }^{\mathrm{a}}$ Unisex life tables used in the NDC plan.

${ }^{\mathrm{b}}$ Maximum benefit is set implicitly by the maximum contribution rate; see Chłon-Domińczak and Strzelecki (2013).

${ }^{\mathrm{c}}$ Majority chose to the participate in NDC plan; see Chłoń-Domińczak (2002).

${ }^{\mathrm{d}}$ Replacement rate defined as the ratio of first benefit to last salary. Calculations from Chłon, Góra, and Rutkowski (1999), pp. 36-37, and Chłoń-Domińczak (2002), p.128. Simulation assumes the statutory retirement age under both regimes: 60 for women, 65 for men. 
Table 2: Between-cohort variation in the post-reform pension system

\begin{tabular}{|c|c|c|c|}
\hline Cohorts & Born $\leq$ December 31, 1948 & $\begin{array}{l}\text { Born between January 1, } 1949 \text { and December 31, } 1968 \\
\text { (transitory cohorts) }\end{array}$ & Born $\geq$ January 1, 1969 \\
\hline Benefit formula & Pre-reform formula. & Post-reform formula with some exceptions. & Post-reform formula. \\
\hline Exceptions to the benefit formula? & No & $\begin{array}{l}\text { Separate rules for the first five cohorts of women (born } \\
\text { 1949-1953). } \\
\text { The } 1949 \text { cohort receives part of the benefit according to the } \\
\text { old pension system formula ( } 80 \% \text { ) and the rest according to } \\
\text { the new formula (20\%). } \\
\text { The } 1950 \text { cohort receives a } 70 / 30 \% \text { mix. } \\
\text { The } 1951 \text { cohort receives a } 55 / 45 \% \text { mix. } \\
\text { The } 1952 \text { cohort receives a } 35 / 65 \% \text { mix. } \\
\text { The } 1953 \text { cohort receives a } 20 / 80 \% \text { mix. }\end{array}$ & No \\
\hline Early retirement provisions? & Yes & $\begin{array}{l}\text { Yes, conditional on age and contribution requirement being } \\
\text { fulfilled before December 31, } 2007 .\end{array}$ & $\begin{array}{l}\text { No early retirement } \\
\text { provisions. In the post- } \\
\text { reform system men retire at } \\
\text { age } 65 \text { and women at age } \\
60 .\end{array}$ \\
\hline
\end{tabular}

NOTE: ${ }^{a}$ From Chłoń, Góra, and Rutkowski (1999), p. 21. 
Table 3: Descriptive statistics

\begin{tabular}{|c|c|c|c|}
\hline Variable & Mean & Std. dev. & Median \\
\hline \multicolumn{4}{|l|}{ Dependent variables } \\
\hline Log available household income & 7.74 & 0.47 & 7.74 \\
\hline Log household expenditure & 7.65 & 0.51 & 7.64 \\
\hline Saving rate & 0.02 & 0.51 & 0.09 \\
\hline Household expenditure (in 2005 PLN) & 2,417 & 1,568 & 2,078 \\
\hline Available household income (in 2005 PLN) & 2,577 & 1,264 & 2,308 \\
\hline Saving (in 2005 PLN) & 160 & 1,292 & 189 \\
\hline Saving is positive (proportion) & 0.64 & 0.48 & \\
\hline \multicolumn{4}{|l|}{ Characteristics of head of household } \\
\hline Age of head of household & 40.4 & 9.11 & \\
\hline Head of household is a woman & 0.32 & & \\
\hline \multicolumn{4}{|l|}{ Marital status } \\
\hline Unmarried & 0.09 & & \\
\hline Married & 0.81 & & \\
\hline Widowed & 0.03 & & \\
\hline Divorced or Separated & 0.07 & & \\
\hline \multicolumn{4}{|l|}{ Educational attainment } \\
\hline Tertiary education & 0.16 & & \\
\hline Postsecondary non-tertiary education & 0.03 & & \\
\hline Upper secondary education & 0.06 & & \\
\hline Lower secondary vocational education & 0.29 & & \\
\hline Gymnasium & 0.02 & & \\
\hline Primary vocational education & 0.37 & & \\
\hline Primary education & 0.08 & & \\
\hline Pre-primary education & 0.02 & & \\
\hline \multicolumn{4}{|l|}{ Occupation $^{\mathrm{a}}$} \\
\hline Legislators, senior officials and managers & 0.09 & & \\
\hline Professionals & 0.11 & & \\
\hline Technicians and associate professionals & 0.12 & & \\
\hline Clerks & 0.09 & & \\
\hline Service workers and shop sales workers & 0.09 & & \\
\hline Craft and related trades workers & 0.27 & & \\
\hline Plant and machine operators and assemblers & 0.13 & & \\
\hline Elementary occupations & 0.09 & & \\
\hline Armed forces & 0.01 & & \\
\hline Works in the private sector & 0.52 & & \\
\hline $\begin{array}{l}\text { Belongs to the cohort unaffected directly by the } \\
\text { reform }\end{array}$ & 0.12 & & \\
\hline Belongs to the older cohort affected by the reform & 0.18 & & \\
\hline $\begin{array}{l}\text { Belongs to the middle-aged cohort affected by the } \\
\text { reform }\end{array}$ & 0.51 & & \\
\hline Belongs to the younger cohort affected by the reform & 0.20 & & \\
\hline \multicolumn{4}{|l|}{ Characteristics of the household } \\
\hline Labor income (in 2005 PLN) & 3,063 & 1,799 & 2,527 \\
\hline Pension benefit (in 2005 PLN) & 1,540 & 633 & 1,526 \\
\hline Pension wealth (in 2005 PLN) & 13,100 & 6,853 & 11,384 \\
\hline Number of persons & 3.53 & 1.34 & \\
\hline Number of children below the age of 15 & 0.88 & 1.00 & \\
\hline \multicolumn{4}{|l|}{ Age difference between spouses } \\
\hline Spouse older than head of household & 0.47 & & \\
\hline
\end{tabular}


Spouse younger than head of household

No spouse

Household owns the place of residence

Year of observation

Year is 1997

Year is 1998

Year is 1999

Year is 2000

Year is 2001

Year is 2002

Year is 2003
0.33

0.20

0.59

0.14

0.14

0.14

0.16

0.14

0.14

0.14

Number of observations

107,708

NOTE: "Saving” is defined as available household income minus total household expenditure. "Saving rate" is defned as saving divided by available household income.

a "Occupation" is presented here at the 1-digit level. 
Table 4: OLS, 2SLS, LIML, QR, and IV-QR crowd-out estimates of the effect of pension wealth on household saving rate, log of expenditure, and saving (in levels)

A.

OLS

\begin{tabular}{lccc}
\hline Variables & $\begin{array}{c}\text { Saving rate } \\
(1)\end{array}$ & $\begin{array}{c}\text { Log expenditure } \\
(2)\end{array}$ & $\begin{array}{c}\text { Saving } \\
(3)\end{array}$ \\
\hline & & & \\
Pension wealth & -0.001 & -0.001 & $0.02^{* * *}$ \\
& $(0.00)$ & $(0.00)$ & $(0.00)$
\end{tabular}

B.

OLS

\begin{tabular}{lccc}
\hline Variables & $\begin{array}{c}\text { Saving rate } \\
(4)\end{array}$ & $\begin{array}{c}\text { Log expenditure } \\
(5)\end{array}$ & $\begin{array}{c}\text { Saving } \\
(6)\end{array}$ \\
\hline & & & \\
Adjusted pension wealth & -0.01 & -0.02 & $0.65^{* * *}$ \\
& $(0.01)$ & $(0.01)$ & $(0.04)$
\end{tabular}

C.

2SLS

\begin{tabular}{|c|c|c|c|}
\hline Variables & $\begin{array}{l}\text { Saving rate } \\
\text { (7) }\end{array}$ & $\begin{array}{c}\text { Log expenditure } \\
\text { (8) }\end{array}$ & $\begin{array}{l}\text { Saving } \\
\text { (9) }\end{array}$ \\
\hline Adjusted pension wealth & $\begin{array}{c}-0.24 * * \\
(0.10)\end{array}$ & $\begin{array}{l}0.21 * * \\
(0.08)\end{array}$ & $\begin{array}{c}-0.57 * * * \\
(0.20)\end{array}$ \\
\hline IV F-statistic & 44.52 & 44.52 & 997.1 \\
\hline$J$-test $p$-value & 0.303 & 0.000455 & 0.525 \\
\hline Number of IV & 3 & 3 & 3 \\
\hline D. & & LIML & \\
\hline Variables & $\begin{array}{c}\text { Saving rate } \\
(10)\end{array}$ & $\begin{array}{c}\text { Log expenditure } \\
(11)\end{array}$ & $\begin{array}{l}\text { Saving } \\
(12)\end{array}$ \\
\hline Adjusted pension wealth & $\begin{array}{c}-0.24^{* *} \\
(0.10)\end{array}$ & $\begin{array}{c}0.24^{* * *} \\
(0.09)\end{array}$ & $\begin{array}{c}-0.57^{* * *} \\
(0.20)\end{array}$ \\
\hline IV F-statistic & 44.52 & 44.52 & 997.1 \\
\hline Anderson-Rubin test $p$-value & 0.303 & 0.000481 & 0.525 \\
\hline Number of IV & 3 & 3 & 3 \\
\hline Observations, $N$ & 107,708 & 107,708 & 107,708 \\
\hline
\end{tabular}

NOTE: Robust standard errors are in parentheses $\left(* * * p<0.01,{ }^{* *} p<0.05, * p<0.1\right)$. Each cell shows a $\theta$ estimate from a different regression. In rows $\mathrm{B}, \mathrm{C}$, and $\mathrm{D}$, pension wealth is adjusted by the $Q$-factor described in Appendix B. Regressions that use either saving rate or log expenditure as the dependent variable use pension wealth normalized by income. Omitted categories: "Born 1937-1948” and years 1997 and 1998. Other controls include month-of-year dummies, a quadratic polynomial in age, gender, number of children, marital status, education, a dummy for whether the head of household's spouse is younger, occupation dummies, a dummy for working in the private sector, a dummy for whether the household owns its place of residence, a "post-reform" dummy, and three cohort dummies (older cohort, born 1949-1953, middle-aged cohort, born 1954-1968; and younger cohort, born 1969-1980). The instrumental variables consist of interaction terms between the "postreform” dummy and the three cohort dummies. 
Table 5: Heterogeneity analysis: 2SLS crowd-out estimates of pension wealth, by cohort

A. Older cohort

\begin{tabular}{|c|c|c|c|}
\hline Variables & Saving rate & Log expenditure & Saving \\
\hline Adjusted pension wealth & $\begin{array}{l}-1.09 * \\
(0.61)\end{array}$ & $\begin{array}{c}1.81^{* * *} \\
(0.60)\end{array}$ & $\begin{array}{c}-0.97 * * \\
(0.49)\end{array}$ \\
\hline $\begin{array}{l}\text { IV F-statistic }(1, N \text {-k) } \\
\text { Average age of the affected } \\
\text { cohort }\end{array}$ & 64.81 & $\begin{array}{l}64.81 \\
49.46\end{array}$ & 419.3 \\
\hline \multicolumn{4}{|c|}{ B. Middle-aged cohort } \\
\hline \multicolumn{4}{|l|}{ Variables } \\
\hline Adjusted pension wealth & $\begin{array}{c}-0.45^{* * *} \\
(0.15)\end{array}$ & $\begin{array}{c}0.54^{* * *} \\
(0.13)\end{array}$ & $\begin{array}{c}-0.78 * * * \\
(0.24)\end{array}$ \\
\hline $\begin{array}{l}\text { IV F-statistic }(1, N \text {-k) } \\
\text { Average age of the affected } \\
\text { cohort }\end{array}$ & 80.36 & $\begin{array}{l}80.36 \\
40.48\end{array}$ & 1001 \\
\hline Observations, $N$ & & 67,482 & \\
\hline \multicolumn{4}{|c|}{ C. Younger cohort } \\
\hline Variables & Saving rate & Log expenditure & Saving \\
\hline Adjusted pension wealth & $\begin{array}{c}-0.29 * * * \\
(0.08)\end{array}$ & $\begin{array}{c}0.18 * * \\
(0.07)\end{array}$ & $\begin{array}{c}-0.82 * * * \\
(0.21)\end{array}$ \\
\hline $\begin{array}{l}\text { IV F-statistic }(1, N \text {-k) } \\
\text { Average age of the affected } \\
\text { cohort }\end{array}$ & 111.5 & $\begin{array}{c}111.5 \\
27.8\end{array}$ & 746.2 \\
\hline Observations, $N$ & & 34,359 & \\
\hline
\end{tabular}

NOTE: Robust standard errors are in parentheses (*** $p<0.01, * * p<0.05, * p<0.1$ ). Each cell shows a 2SLS $\theta$ estimate from a different regression. Pension wealth is adjusted by the $Q$-factor described in Appendix B. Each regression uses a dependent variable that has been residualized with respect to month-of-year dummies, a quadratic polynomial in age, gender, number of children, marital status, education, a dummy for whether the head of household's spouse is younger, occupation dummies, a dummy for working in the private sector, and a dummy for whether the household owns its place of residence. The regression controls a "post-reform" dummy (with "Born 1937-1948" being the omitted category) and an "affected cohort" dummy (with years 1997 and 1998 being omitted categories). The instrumental variable is defined as an interaction term between the "postreform" dummy and the "affected cohort" dummy. 
Table 6: Heterogeneity analysis: 2SLS crowd-out estimates of pension wealth for selected subsamples of households

\section{Head of household has at least tertiary education}

\begin{tabular}{lccc}
\hline Variables & Saving rate & Log expenditure & Saving \\
\hline Adjusted pension wealth & $-1.70^{* * *}$ & $0.84^{* *}$ & $-1.69^{* *}$ \\
& $(0.52)$ & $(0.42)$ & $(0.70)$ \\
IV F-statistic & 459.4 & 459.4 & 118.2 \\
Observations, $N$ & 17,103 & 17,103 & 17,103
\end{tabular}

Household owns the place of residence

\begin{tabular}{lccc}
\hline Variables & Saving rate & Log expenditure & Saving \\
\hline Adjusted pension wealth & -0.16 & $0.35^{* *}$ & $-0.56^{*}$ \\
& $(0.17)$ & $(0.15)$ & $(0.30)$ \\
IV F-statistic & 9.906 & 9.906 & 533.1 \\
Observations, $N$ & 63,220 & 63,220 & 63,220 \\
Number of IV & 3 & 3 & 3 \\
\hline
\end{tabular}

\section{Head of household has less than tertiary education}

\begin{tabular}{ccc}
\hline Saving rate & Log expenditure & Saving \\
\hline-0.14 & $0.14^{*}$ & $-0.40^{* *}$ \\
$(0.10)$ & $(0.08)$ & $(0.19)$ \\
35.81 & 35.81 & 1057 \\
90,605 & 90,605 & 90,605
\end{tabular}

Household does not own the place of residence

\begin{tabular}{ccc}
\hline Saving rate & Log expenditure & Saving \\
\hline$-0.25^{* *}$ & 0.04 & $-0.46^{*}$ \\
$(0.10)$ & $(0.09)$ & $(0.25)$ \\
535.5 & 535.5 & 473.7 \\
44,488 & 44,488 & 44,488 \\
3 & 3 & 3 \\
\hline
\end{tabular}

NOTE: Robust standard errors are in parentheses $(* * * p<0.01, * * p<0.05, * p<0.1)$. Each cell shows a 2SLS $\theta$-estimate from a different regression. Pension wealth is adjusted by the $Q$-factor described in Appendix B. Big city is defined as a city with 500,000 or more inhabitants. Regressions that use either saving rate or log expenditure as the dependent variable use pension wealth normalized by income. Omitted categories: "Born 1937-1948" and "Year 1998." Same controls as in Table 4. The instrumental variables consist of interaction terms between the "post-reform" dummy and the three cohort dummies. 
Table 7: Robustness check: crowd-out estimates of the pension wealth using alternative analysis samples

\begin{tabular}{|c|c|c|c|}
\hline Variables & $\begin{array}{l}\text { Saving rate } \\
\text { (1) }\end{array}$ & $\begin{array}{l}\text { Log expenditure } \\
(2)\end{array}$ & $\begin{array}{l}\text { Saving } \\
(3)\end{array}$ \\
\hline Adjusted pension wealth & $\begin{array}{l}-0.22 * * \\
(0.10)\end{array}$ & $\begin{array}{l}0.14 \\
(0.09)\end{array}$ & $\begin{array}{c}-0.59 * * \\
(0.24)\end{array}$ \\
\hline $\begin{array}{l}\text { IV F-statistic } \\
\text { Number of IV }\end{array}$ & $\begin{array}{c}1198 \\
3\end{array}$ & $\begin{array}{c}1198 \\
3\end{array}$ & $\begin{array}{c}650.8 \\
3\end{array}$ \\
\hline Observations, $N$ & 92,203 & 92,203 & 92,203 \\
\hline \multicolumn{4}{|c|}{$\begin{array}{l}\text { Specification 2: sample restricted to } 18-60 \text { male heads of household and } \\
\text { 18-55 female heads of households }\end{array}$} \\
\hline Variables & $\begin{array}{l}\text { Saving rate } \\
\text { (1) }\end{array}$ & $\begin{array}{c}\text { Log expenditure } \\
(2)\end{array}$ & $\begin{array}{l}\text { Saving } \\
\text { (3) }\end{array}$ \\
\hline Adjusted pension wealth & $\begin{array}{c}-0.23 * * \\
(0.10)\end{array}$ & $\begin{array}{c}0.21^{* *} \\
(0.09)\end{array}$ & $\begin{array}{c}-0.54^{* * *} \\
(0.20)\end{array}$ \\
\hline IV F-statistic & 41.99 & 41.99 & 955.5 \\
\hline Number of IV & 3 & 3 & 3 \\
\hline Observations, $N$ & 106,364 & 106,364 & 106,364 \\
\hline
\end{tabular}

NOTE: Robust standard errors are in parentheses $(* * * p<0.01, * * p<0.05, * p<0.1)$. Each cell shows a 2SLS $\theta$ estimate from a different regression. Pension wealth is adjusted by the $Q$-factor described in Appendix B. Regressions that use either saving rate or log expenditure as the dependent variable use pension wealth normalized by income. Omitted categories: "Born 1937-1948" and "Year 1998." Same controls as in Table 4. The instrumental variables consist of interaction terms between the "post-reform" dummy and the three cohort dummies. 
Table 8: Robustness check: 2SLS crowd-out estimates of pension wealth using alternative specifications

Specification 1: older cohort and middle-aged cohort pooled together

\begin{tabular}{lccc}
\hline Variables & $\begin{array}{c}\text { Saving rate } \\
(1)\end{array}$ & $\begin{array}{c}\text { Log expenditure } \\
(2)\end{array}$ & $\begin{array}{c}\text { Saving } \\
(3)\end{array}$ \\
\hline Adjusted pension & & & \\
wealth & $-0.26^{* *}$ & $0.16^{*}$ & $-0.67^{* * *}$ \\
& $(0.11)$ & $(0.09)$ & $(0.22)$ \\
IV F-statistic & 53.54 & 53.54 & 1283 \\
Number of IV & 2 & 2 & 2 \\
\hline
\end{tabular}

Specification 2: pension wealth calculation assumes that men retire at 55 years of age and women at 50 years of age

\begin{tabular}{lccc}
\hline Variables & $\begin{array}{c}\text { Saving rate } \\
(4)\end{array}$ & $\begin{array}{c}\text { Log expenditure } \\
(5)\end{array}$ & $\begin{array}{c}\text { Saving } \\
(6)\end{array}$ \\
\hline Adjusted pension & & & \\
wealth & $-0.20 * * *$ & $0.19 * * *$ & $-0.39 * * *$ \\
& $(0.08)$ & $(0.07)$ & $(0.13)$ \\
IV F-statistic & 56.87 & 56.87 & 2486 \\
Number of IV & 3 & 3 & 3 \\
\hline
\end{tabular}

Specification 3: pension wealth calculation assumes that women contribute to the pension system for 10 years

\begin{tabular}{lccc}
\hline Variables & $\begin{array}{c}\text { Saving rate } \\
(7)\end{array}$ & $\begin{array}{c}\text { Log expenditure } \\
(8)\end{array}$ & $\begin{array}{c}\text { Saving } \\
(9)\end{array}$ \\
\hline Adjusted pension & & & \\
wealth & $-0.21^{*}$ & 0.12 & $-0.43^{*}$ \\
& $(0.11)$ & $(0.09)$ & $(0.26)$ \\
IV F-statistic & 36.46 & 36.46 & 596.5 \\
Number of IV & 3 & 3 & 3 \\
\hline
\end{tabular}

Specification 4: pension wealth calculation uses OLS to calculate lifetime earnings

\begin{tabular}{lccc}
\hline Variables & $\begin{array}{c}\text { Saving rate } \\
(10)\end{array}$ & $\begin{array}{c}\text { Log expenditure } \\
(11)\end{array}$ & $\begin{array}{c}\text { Saving } \\
(12)\end{array}$ \\
\hline Adjusted pension & & & \\
wealth & $-0.23^{* *}$ & $0.20^{* *}$ & $-0.53^{* * *}$ \\
& $(0.09)$ & $(0.08)$ & $(0.19)$ \\
IV F-statistic & 46.43 & 46.43 & 1203 \\
Number of IV & 3 & 3 & 3 \\
\hline & & & \\
Observations & 107,708 & 107,708 & 107,708 \\
\hline
\end{tabular}

NOTE: Robust standard errors are in parentheses $(* * * p<0.01, * * p<0.05, * p<0.1$ ). Each cell shows a 2SLS $\theta$ estimate from a different regression. Pension wealth is adjusted by the $Q$-factor described in Appendix B. Regressions that use either saving rate or log expenditure as the dependent variable use pension wealth normalized by income. Omitted categories: "Born 1937-1948” and years 1997 and 1998. Same controls as in Table 4. The instrumental variables consist of interaction terms between the "post-reform" dummy and the three cohort dummies. 


\section{Appendix A: Sample and variable definitions}

In order to calculate future pension benefits, we make several assumptions. In this appendix, we discuss the main assumptions and the steps used in our calculations.

\section{A.1 Sample selection}

1. In order to reduce the influence of outliers, for each year of the BBGD, we trim the available household income below the first and above the ninety-ninth percentile.

2. In years 1998, 1999, 2000, 2003, and 2004, the BBGD contains information on year of birth. In other years, we compute it as the difference between the year and month of the survey and the current age of the respondents.

3. We keep households whose head was born between 1937 and 1980; hence, the age of the head of household ranges between 19 and 62 years at the time of the reform. Each year, the sample is restricted to include 18- to 65-year-old heads of household.

4. We only include households for whom we observe the head of household's occupation at the time of the survey. The information on occupations is necessary for the computation of lifetime labor income (see below).

5. We drop all the households where the head or the spouse works in farming or in the agricultural industry, or if the main household income comes from agriculture. We do this because farmers were outside of the regular pension system and because income and consumption information is not very informative of the saving behavior of these households.

6. We drop households whose main source of income comes from pensions.

7. The final sample consists of 107,708 observations, with about $14,600-17,000$ observations in each year of data. 


\section{A.2 Lifetime labor income profiles}

- Labor income in the BBGD is measured net of taxes and social security contributions. We use the SIMPL tax-benefit micro simulation model for Poland (see Bargain et al. 2007) to gross up the net labor incomes to include taxes and social security contributions. We define total labor income for each person as the sum of labor income from temporary and permanent employment in the private and public sector, and we express all values in 2005-constant prices.

- We forecast labor income (earnings) separately for heads of households and spouses using the 1997-2003 waves of the BBGD. For heads of households, we calculate the labor income profiles by estimating ordinary-least-square regressions of the income of the head of household on age, age squared, gender, marital status, interaction between gender and marital status, education level, occupation dummies, industry dummies, year dummies, and indicators for decade of birth. The latter is controlled for in order to allow cohort-specific intercepts to reflect differences in cohort productivity. We use the predicted earnings profile to forecast labor income for each head of household, given his (her) characteristics, from the age the head of household was at the time, 23 (25), until 60 (55).

- We model the earnings process separately for female and male spouses. For female spouses (77 percent of spouses are women) we forecast the earnings profiles using a Heckman selection correction. This is done to include the large number of zero labor incomes of this group. The labor income of the spouse is regressed on age, age squared, education-level dummies, occupation dummies, industry dummies, decadeof-birth dummies, and year dummies. The "selection equation” for labor force participation (defined as labor earnings greater than zero) uses age, age squared, the number of children in the household who are 14 or younger, an interaction term 
between age and the number of children, the level of education, and decade-of-birth dummies. For male spouses we estimate labor income profiles by ordinary-leastsquare regressions of the labor income of the male spouse on age, age squared, education-level dummies, occupation dummies, industry dummies, indicators for decade of birth, and year dummies. We use the predicted earnings profiles to forecast labor income for each spouse, given his (her) characteristics, from the age the spouse was at the time, 23 (25), until 60 (55).

- When computing the lifetime earning profiles, we assume that, except for age and its square, all the current characteristics are fixed and the profile changes with age and its square term.

\section{A.3 Pension benefit and pension wealth calculation}

We calculate the future public pension benefits based on the entitlement that individuals will have acquired by the time they transition into old-age retirement according to the legislation at the time of the observation. Hence, the changes induced by the pension reform will reflect on the expected pension benefits in the years 1999-2003. In 1997 and 1998, the expected pension benefits are calculated according to the pre-reform legislation.

\section{$\underline{\text { Pre-reform pension benefits }}$}

In the pre-reform system (see Chłon-Domińczak [2002]), the old-age pension formula consisted of a common economy-wide component and an individual earnings-based component.

The common economy-wide component of the pension benefit consisted of 24 percent of the economy-wide average earnings. The individual earnings-based component was based on the individual's 10 best consecutive years of work out of the 20 years prior to retirement. This 
individual-based average was then multiplied by the number of years of work contributions and by 1.3 percent. In the pre-reform system, non-work contributory years also counted (for example, years spent in college, in military service, and on maternity leave), and the individual-based average was multiplied by a factor of 0.7 percent. In the pre-reform system, there were also a minimum pension and a maximum. The individual earnings-based component was capped at a maximum of 2.5 times the economy-wide average earnings. The minimum pension benefit was set at 35 percent of the economy-wide average earnings. Specifically, we compute the pre-reform pension benefit as benefit $=\max \left\{0.35 B A, 0.24 B A+\min \{C A E, 2.5 B A\} \times\left(0.013 C_{W}+0.007 C_{N W}\right)\right\}$.

- BA stands for the basic amount — that is, the average economy-wide earnings published by the Polish Statistical Office, Główny Urząd Statystyczny (GUS).

- $C A E$ stands for countable average earnings - that is, the average of the 10 best years of work contributions out of the last 20 years.

- $C_{W}$ stands for years of work contributions, which were at least 20 years for women and 25 for men.

- $C_{N W}$ stands for years of non-work contributions (for example, military service or maternity leave), which were limited to a maximum of one-third of the total number of years of contributions.

Assumptions for computing pre-reform benefits: We compute the 10 best years of each individual based on the forecast lifetime earnings profiles described previously. In our calculations, we assume that men and women contribute fully to the system, according to the pre-reform legislation: 25 years of work contributions for men and 20 for women. We also assume that men have three years of non-work contributions (at the time, there was a two-year compulsory military service) and that women have five years of non-work contributions. We 
assume that women retire at 55 and men at 60 . Since the pre-reform minimum pension benefit was benchmarked to the economy-wide average earnings published by GUS, we assume that this economy-wide average grows by 2 percent annually in real terms.

\section{$\underline{\text { Post-reform pension benefits and initial capital }}$}

The cohorts we study who have participated for at least one year in the pre-reform system were entitled to an "initial capital" sum that converted the contributions they had made so far into a starting capital sum, beginning as of 1999 for the reformed NDC plan; Chłoń-

Domińczak (2002, p. 126) provides a detailed explanation of how the initial capital sum was computed.

The formula for the initial capital requires computing a correction factor, CF:

$$
C F=\min \left\{1, \sqrt{\frac{\text { age in } 1998-18}{\text { retirement age }-18}} \times \frac{\text { years of contributions in } 1998}{\text { required years of contributions }}\right\} \text {, }
$$

where the formula set the retirement age to 60 for women and 65 for men and the required years of contributions to 20 years for women and 25 for men. The initial capital is computed as $0.24 \times B A \times C F \times G_{62}$, where $G_{62}$ is the unisex life expectancy for a 62-year-old in 1998 and $B A$ is the basic amount, defined above.

Assumptions for computing initial capital: In our calculations, we compute years of contributions as of the end of 1998 as the age of an individual in 1998 minus 23 years (minus 25 for women, to account for spotty labor force participation). We compute $G_{62}$ as a simple average of 62-year-old men and women’s life expectancy in 1998.

For the years after the 1999 reform until the year of retirement, we calculate contributions as 19.52 percent of an individual's earnings. The post-reform pension benefit equals

$$
\text { benefit }=\frac{\text { initial capital }+0.1952 \sum_{t=1999}^{\text {year of retirement }} \text { earnings } t}{\text { unisex life expectancy at retirement }} \text {. }
$$


In all our computations, we express all values in 2005-constant prices and assume that the real pension benefits will grow by 4 percent annually. ${ }^{17}$

Assumptions for computing post-reform benefits: We assume that men contribute continuously until they retire at 60 years of age and that women contribute continuously until they retire at 55 years of age. The pension benefit is computed as the sum of initial capital and the contributions of an individual's earnings divided by the remaining unisex life expectancy at the statutory age of retirement.

\section{$\underline{\text { Pension wealth }}$}

The general formula for computing pension wealth is the following:

$$
P W(i)=\sum_{\tau=\text { ret.age }}^{\text {max.age }} \frac{p r_{\tau \mid \text { age }(i)} \times \text { benefit }(i) \times(1+g)^{\tau-r e t . a g e}}{(1+r)^{\tau-\text { age }(i)}}
$$

- $\quad P W(i)$ : pension wealth of an individual $i$.

- ret.age: retirement age, set at 65 for men and 60 for women.

- max.age: maximum attainable age, set at 100 years (the end of the life table).

- $p r_{\tau \mid \text { age }(i)}$ : the probability that someone aged age(i) will be alive at age $\tau=$ ret.age, ..., max.age. ${ }^{18}$

- benefit(i): pension benefit of an individual $i$, computed as described above.

- $g$ : real growth rate of pension benefits, set at 0.04 .

- $\quad r$ : real interest rate, set at 0.02 .

To compute pension wealth, we make the following assumptions:

\footnotetext{
${ }^{17}$ By doing so, we implicitly assume that the return on the fully funded pension (7.3 percent contribution to FDC) in the post-reform system has the same return as the notionally defined contribution pension (12.22 percent contribution to the NDC pension), which is financed on a pay-as-you-go basis by current contributions. This is because we 1) do not have the data on households' FDC portfolio choices and 2) ex post, the returns on the FDC plans have performed below initial projections. This is in part because the funds have invested a large share of the portfolios in government bonds, in effect making the FDC pension plan a liability in a similar way as the payas-you-go NDC plan.

${ }^{18}$ We use separate male and female 1999 life tables from the Polish Statistical Office, GUS.
} 
- When calculating pension wealth, we adjust the future stream of pension benefits by using separate male and female survival probabilities from the 1999 Polish life tables. The maximum age is also taken from the life tables and is set to 100 years for everyone.

- We compute the pension benefits separately for the head of the household and the spouse and then take their sum.

- The actuarially adjusted stream of future pension benefits of the head of the household and the spouse is discounted back to the current age of the head of the household.

- Finally, we divide the expected pension wealth by the estimated current labor income of the household.

\section{Appendix B: Adjustment Factor}

Gale $(1998,2005)$ points out that a simple comparison of saving rates at one point in time with a stream of benefits occurring in the future will bias the crowd-out estimates toward zero. Gale (1998) proposes to use instead the so-called “Gale’s Q” adjustment factor (see Bottazzi, Jappelli, and Padula [2006]; Engelhardt and Kumar [2011]; and Alessie, Angelini, and van Santen [2013]), which is a function of the subjective discount rate, the point in the life cycle when an individual is observed, and the point in the life cycle when a change in the expected pension benefits takes place.

For each individual, we multiply pension wealth by a discrete-time version of the adjustment factor (see Attanasio and Brugiavini [2003]; Attanasio and Rohwedder [2003]; Feng, He, and Sato [2011]; and Alessie, Angelini, and van Santen [2013]). In order to develop intuition for this adjustment factor, we first present a simple version of the finite-horizon optimization problem from Attanasio and Rohwedder (2003). Suppose each individual has an initial asset equal to $a_{1}$ that, for simplicity’s sake, does not grow or depreciate. In each period, 
the individual has to decide how much to consume and how much to save for the future.

Assuming log utility, the problem can be expressed as

$$
\max _{\left\{c_{t}, a_{t+1}\right\}_{t=1}^{T}} \sum_{t=1}^{T} \beta^{t-1} \log c_{t} \text { s.t. } a_{t+1}=a_{t}-c_{t} \text { for } t=1, \ldots, T
$$

where $a_{1}>0$ is given, $a_{T+1} \geq 0, c$ denotes consumption, and $\beta$ is the subjective discount factor.

Suppose that, as in Attanasio and Rohwedder (2003), there are four time periods,

$T=4$. The optimal consumption policy is:

$$
\begin{aligned}
& c_{1}=\frac{a_{1}}{1+\beta+\beta^{2}+\beta^{3}}, \\
& c_{2}=\frac{\beta a_{1}}{1+\beta+\beta^{2}+\beta^{3}}=\frac{a_{2}}{1+\beta+\beta^{2}}, \\
& c_{3}=\frac{\beta^{2} a_{1}}{1+\beta+\beta^{2}+\beta^{3}}=\frac{\beta a_{2}}{1+\beta+\beta^{2}}=\frac{a_{3}}{1+\beta}, \\
& c_{4}=\frac{\beta^{3} a_{1}}{1+\beta+\beta^{2}+\beta^{3}}=\frac{\beta^{2} a_{2}}{1+\beta+\beta^{2}}=\frac{\beta a_{3}}{1+\beta}=a_{4} .
\end{aligned}
$$

For $t>1$ we can derive more than one expression. The first expression presented is the optimal consumption for period $t=1,2,3,4$, as seen from period 1 . The second and third expressions show the optimal consumption for period $t=2,3,4$, as seen from periods 2 and 3 , and so on.

If there has been no unexpected change in the periods following $t=1$, then, for each $c_{t}$, the second and third expressions are equal to the first one. ${ }^{19}$ However, if an unexpected change does occur in the periods following $t=1$, then the consumer has to re-optimize her consumption given the level of assets she has carried over from the previous period. For example, if the unexpected change has occurred at the end of period 1 , then in period 2, the level of assets available to the consumer $a_{2}$ is given and cannot be changed retrospectively.

\footnotetext{
${ }^{19}$ This can be verified by plugging in the solution for $c_{t}$ from the first expression into the dynamic budget constraint $a_{t+1}=a_{t}-c_{t}$.
} 
Hence, the level of $c_{2}$ given by the second expression, $\frac{a_{2}}{1+\beta+\beta^{2}}$, will not equal the level of $c_{2}$ from the first expression, $\frac{\beta a_{1}}{1+\beta+\beta^{2}+\beta^{3}}$.

The take-away from this simple model is the illustration that the consumption and saving response following an unexpected change in wealth depends not only on the magnitude of the change in expected wealth, but also on subjective time preferences $(\beta)$, the remaining planning horizon ( $T$ minus the time at which the shock occurs), and the age of the consumer (t). The pattern for the $Q$ adjustment factor if there is no shock can be generalized to $T$ periods using the formula for the sum of a finite geometric series:

$$
Q(t ; t r=0)=\frac{\beta^{t-1}}{1+\beta+\beta^{2}+\cdots+\beta^{T-1}}=\frac{1-\beta}{1-\beta^{T}} \beta^{t-1},
$$

where $t$ denotes a point in a consumer's life cycle. The pattern for this adjustment factor following a shock to wealth in any period $t r>t$ can be expressed as

$$
Q(t, t r)=\frac{\beta^{t-t r-1}}{1+\beta+\beta^{2}+\cdots+\beta^{T-t r-1}}=\frac{1-\beta}{1-\beta^{T-t r}} \beta^{t-t r-1} \text { for } \operatorname{tr}>t,
$$

where tr denotes the point in a consumer's life cycle when the unexpected change occurs.

In practical terms, we must adjust our measure of pension wealth to reflect that we observe individuals at various ages (hence with different remaining life expectancies) who also experience the reform at various points in their life cycle. For each observation $i$, we multiply pension wealth by the adjustment factor:

$$
\frac{(1-\beta) \beta^{\text {age }(i)-\text { start work }}}{1-\beta^{\text {life exp }(i)-\operatorname{age}(i)}}
$$

where age(i) is the current age of the head of household, start work is the age at which the head of household starts working, life exp(i) is calculated as the sum of current age and remaining gender-specific life expectancy, and $\beta$ is set to equal $0.98 .^{20}$

\footnotetext{
${ }^{20}$ As in Feng, He, and Sato (2011), we treat the postretirement period as several time periods.
} 
Following the reform, the affected households need to re-optimize their consumption and saving behavior. The adjustment factor must take into account the household head's remaining life expectancy after the reform, the household head's current age, and when during the head of household's life cycle the reform occurred:

$$
\frac{(1-\beta) \beta^{\text {age }(i)-\text { age at reform }(i)}}{1-\beta^{\text {life exp }(i)-\text { age at reform }(i)},}
$$

where age at reform $(i)$ is the head of household's age at the end of $1998+1$, as we assume that the reform occurs at the end of 1998 and that 1999 is the first year of the reform. We apply the factor $\frac{(1-\beta) \beta^{\text {age }(i) \text {-age at reform }(i)}}{1-\beta^{\text {life exp }(i)-\text { age at reform(i) }}}$ to all the households affected by the reform and $\frac{(1-\beta) \beta^{\text {age }(i)-\text { start work }}}{1-\beta^{\text {life exp }(i)-a g e(i)}}$ to the households unaffected by the reform and households in the prereform period. 


\section{Appendix C: Other results}

Figure A.1: Estimated effect of the 1999 pension reform on saving rate, by cohort

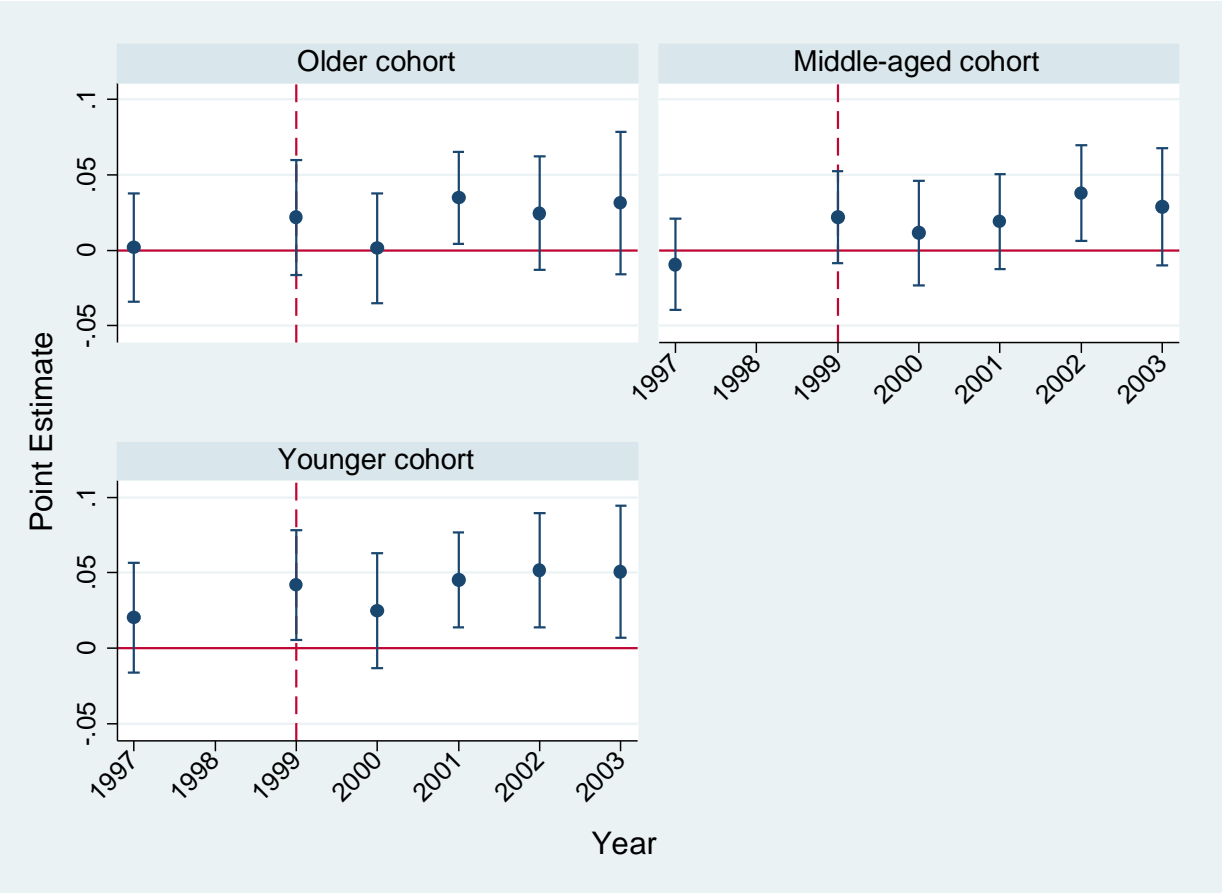

NOTE: The figure above shows point estimates from a multiyear difference-in-differences regression of the saving rate on three cohort dummies (older cohort, born 1949-1953; middle-aged cohort, born 1954-1968; and younger cohort, born 1969-1980), six year dummies, cohort-by-year interaction terms, and controls from Table 3. For each cohort, each panel presents the cohort-by-year interaction point estimate over time. The omitted categories are Year 1998 (the year before the reform) and the cohort born 1937-1948 (the cohort unaffected by the reform). The regression uses robust standard errors clustered by year of birth, and the figure presents 95 percent confidence intervals. The dashed vertical line indicates the first year of the reform. 
Figure A.2: Estimated effect of the 1999 pension reform on saving (in levels), by cohort

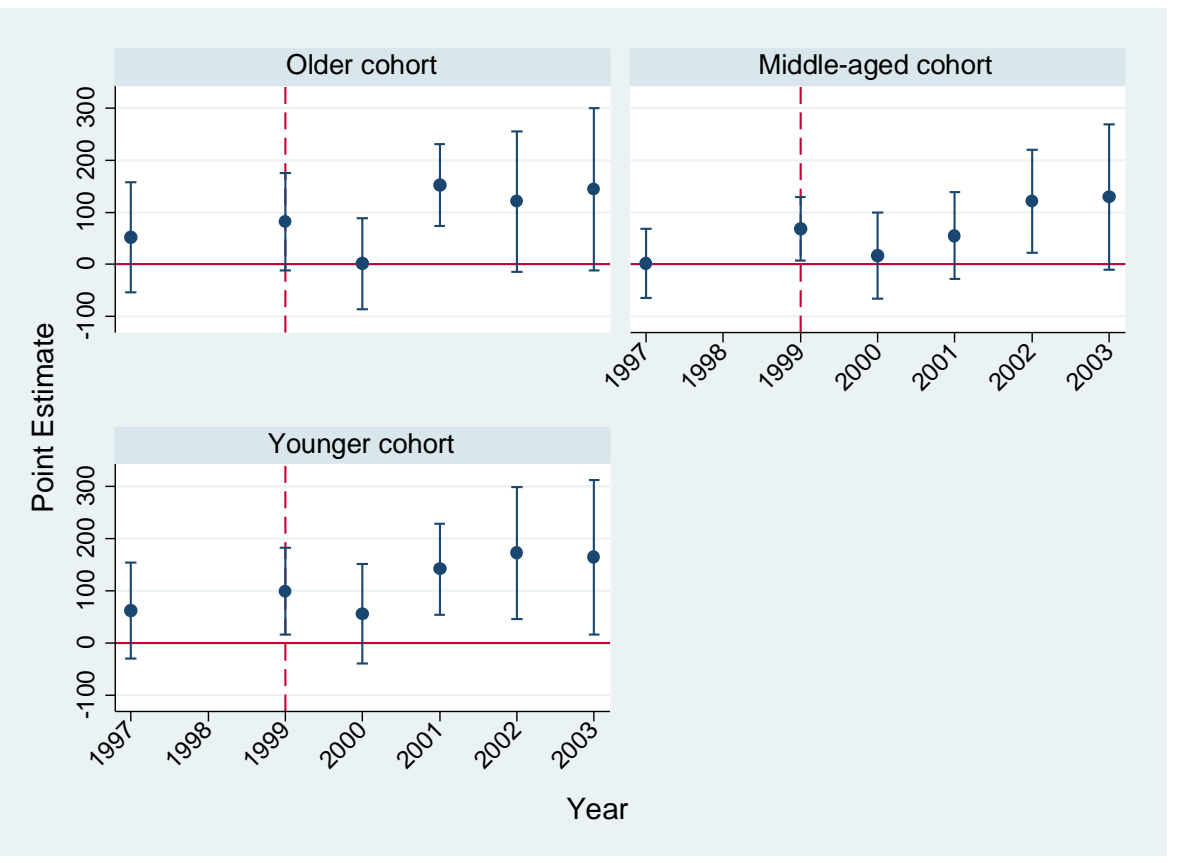

Figure A.3: Estimated effect of the 1999 pension reform on log expenditure, by cohort

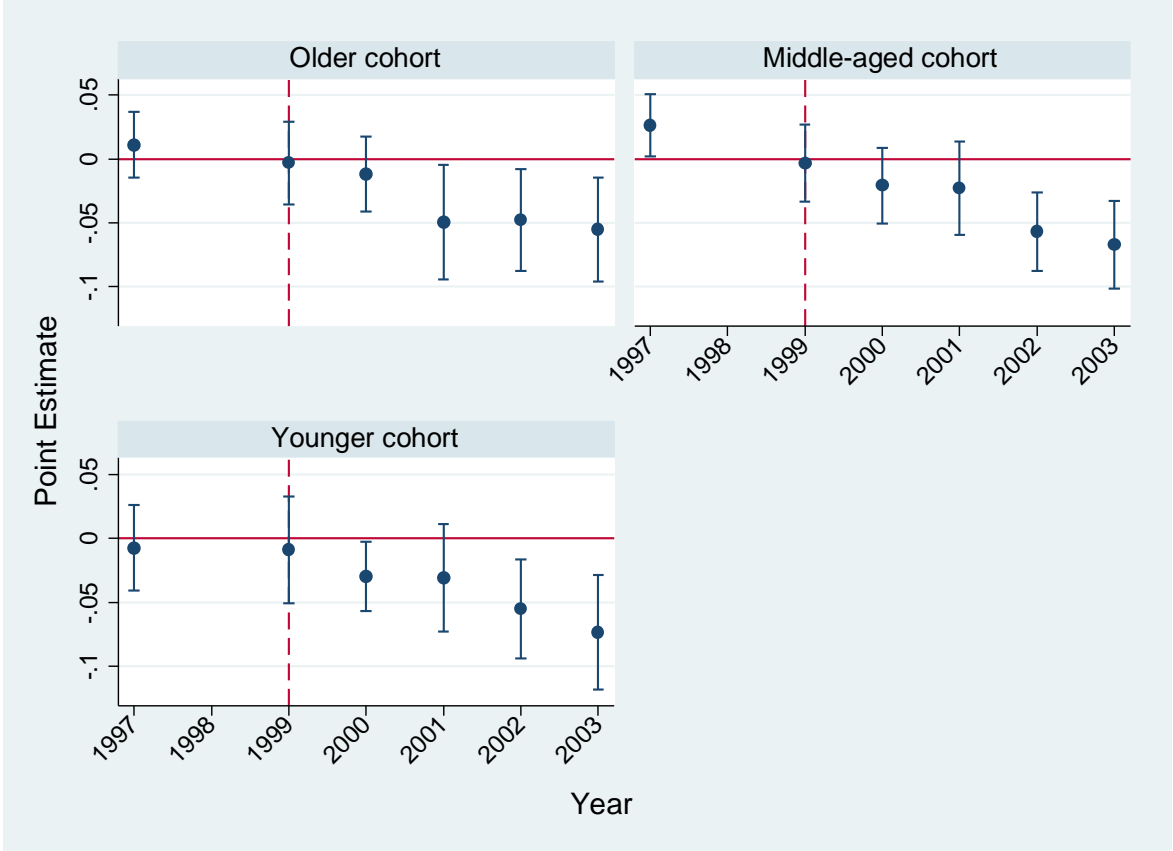

NOTE: The figure above shows point estimates from a multiyear difference-in-differences regression of saving (top) and log expenditure (bottom) on three cohort dummies (older cohort, born 1949-1953; middle-aged cohort, born 1954-1968; and younger cohort, born 1969-1980), six year dummies, cohort-by-year interaction terms, and controls from Table 3. For each cohort, each panel presents the cohort-by-year interaction point estimate over time. The omitted categories are Year 1998 (the year before the reform) and the cohort born 1937-1948 (the cohort unaffected by the reform). The regression uses robust standard errors clustered by year of birth, and the figure presents 95 percent confidence intervals. The dashed vertical line indicates the first year of the reform. 